\title{
ENCOUNTERS ON THE FRONTIERS OF INTERNATIONAL HUMAN RIGHTS LAW: REDEFINING THE TERMS OF INDIGENOUS PEOPLES' SURVIVAL IN THE WORLD
}

\author{
ROBERT A. WILliAMS, JR.*
}

\section{INTRODUCTION}

The global movement for human rights is redefining the world as we know it. Our contemporary ideas about law-once so stable, so sure that law was made and remade according to the positivities of state sovereignty in the world-have failed us. We are not prepared to deal with the sudden emergence of human values as reflected in a global discourse that mightly beams its vision of rights into our homes.

We now realize that we hive in very complex times. On all fronts, intellectual and material, we witness the crumbling of previously uncontested boundaries. Some of the great canomical texts of Western civilization are beimg questioned, not only in our umiversities, but im the capitals of the world as well.

Not too long ago, it was fashionable for some legal academics $i m$ this country to assert that rights discourse-that is, talk and thought about rights-was actually harmful to the social movements of peoples of color and other oppressed groups. ${ }^{1}$ And as recent times have shown, legal aca-

\footnotetext{
Copyright () Robert A. Williams, Jr. 1990.

* Professor of Law, and Acting Director, Office of Indian Programs, University of Arizona. J.D., 1980, Harvard Law School. Member, Lumbee Indian Tribe of North Carolina. I would like to thank James Anaya, Howard Berman, Tim Coulter, Hurst Hannum, and Douglas Sanders for their helpful comments and discussions with ine on nany of the issues discussed in this Article. I would also like to thank the Jolin D. and Catherine T. MacArthur Foundation and the National Endowment for the Humanities for their support of my research project on historical and contenuporary North American indigenous visions of international law and peace, of which this Article is a part. Support from the Umiversity of Arizona Office of International Programs, Graduate College Small Grants Program, and College of Law Alumni Fund is also gratefully acknowledged.

1. See Crenshaw, Race, Reform, and Retrenchment: Transformation and Legitimation in Antidiscrimination Law, 101 HARV. L. REv. 1331, 1352-56 (1988) (discussing the critique of rights and rights discourse foimd in the works of critical legal scholars (CLS) such as Alan Frecnian, Mark Tuslinet, and Peter Gabel); Delgado, The Ethereal Scholar: Does Critical Legal Studies Have What Minorities Want?, 22 HARV. C.R.-C.L. L. REV. 301 (1987) (assessing various critical legal studies perspectives and their usefulness in containing and eliminating racisn); $\mathbf{R}$. Williams, Taking Rights Aggressively: The Perils and Promise of Critical Legal Studies for Peoples of Color, 5 LAW \& INEQUALITY 103 (1987) (discussing critical legal studies' negative assessinents of the efficacy of rights
} 


\section{demics of color can attract a great deal of attention and the sympathies of anonymous white colleagues by telling us that the sufferings and stories}

rhetoric). On uses of narratives and storytelling in critical race scholarship, see, e.g., D. BEIL, AND We ARE NOT SAVED 6 (1987) (noting that a "lawyer's primary task is translating human stories into legal stories and retranslating legal story endings into solutions to human problems"; Delgado, Storytelling for Oppositionists and Others: A Plea for Narrative, 87 MrcH. L. REV. 2411, 2440 (1989) [hereinafter Delgado, Storytelling for Oppositionists] (supporting the use of legal storytelling because it "invites the listener to suspend judgment, listen for the story's point, and test it against his or her own version of reality"; storytelling gains the understanding, if not the support of the white inajority); Matsuda, Public Response to Racist Speech: Considering the Victim's Story, 87 Mich. L. REV. 2320,2380 (1989) (proposing the "criminalization of a narrow, explicitly defined class of racist hate speech, to provide public redress for the unost serions harm, while leaving many forms of racist speech to private remedies"); P. Williams, Alchemical Notes: Reconstructing Ideals from Deconstructed Rights, 22 HARV. C.R.-C.L. L. REV. 401, 432 (1987) (arguing that the task for CLS is "to expand private property rights into a conception of civil rights, into the right to expect civility froun others"). Feminist legal scholars also have relied on narrative as part of their methodology. See, e.g., Littleton, Feminist Jurisprudence: The Difference Method Makes, 41 STAN. L. REV. 751, 75254 (1989) (arguing that Catharine MacKinnon's FEMINISM UNMODIFIED (1987), believes the substance of feminist jurisprudence can be developed through the feminist method of inquiry defined as "believing wounen's accounts of sexual use and abuse by men"; Menkel-Meadow, Feminist Legal Theory, Critical Legal Studies, and Legal Education or the "Fem-Crits Go to Law School," $38 \mathrm{~J}$. LEGAL EDUC. 61, 85 (1988) (eunploying personal narrative to review the similarities and divergences in the critiques of legal education offered by critical legal studies and feminist theory).

Professor Kimberlé Williams Crenshaw has spoken of the usefulness of rights discourse to the civil rights movement in this country in the following terms:

Rights lave been important. They may have legitimated racial imequality, but they have also been the means by which oppressed groups have secured both entry as formal equals into the dominant order and the survival of their movement in the face of private and state repression. ...

The Critics are correct in observing that engaging in rights discourse has lielped to deradicalize and co-opt the challenge. Yet they fail to acknowledge the limited range of options presented to Blacks in a context where they were decined "other," and the unlikelihood that specific deinands for inclusion and equality would be lieard if articulated in other terms.

Crenshaw, supra, at 1384-85.

Professor Ricliard Delgado has described the power of stories to transform the way we think in the following terms:

Stories, parables, chromicles, and narratives are powerful means for destroying mindsetthe bundle of presuppositions, received wisdoms, and shared understandings against a background of which legal and political discourse takes place. These matters are rarely focused on. They are like eyeglasses we have worn a long time. They are nearly imvisible; we use them to scan and interpret the world and ouly rarely examine thein for themselves. Ideology - the received wisdom-makes current social arrangements seein fair and natural. Those in power sleep well at might-their conduct does not seem to theun like oppression.

The cure is storytelling (or as I shall sometimes call it, counterstorytelling). . . .

... Counterstories, which challenge the received wisdoun. ... can open new windows into reality, showing us that there are possibilities for life other than the ones we live. ... Counterstories can quicken and engage conscience. Their graphic quality can stir imagination in ways in which more conventional discourse cannot.

But stories and counterstories can serve an equally important destructive function. They can show that what we believe is ridiculous, self-serving, or cruel. They can sliow us the way out of the trap of unjustified exclusion. They can lielp us understand when it is time to rcallocate power. They are the other half-the destructive lialf-of the creative dialeetic.

Delgado, Storytelling for Oppositionists, supra, at 2413-15 (footuotes ouritted). 
of peoples of color in this eountry possess no unique capacity to transform the law. ${ }^{2}$

These legal academic denials of the efficacy of rights discourse and storytelling for the social inoveinents of peoples of color now seem disharmonious with the larger transformations occurring in the world. Why any legal academics would discount the usefulness of such proven, liberating forms of discourse in the particular society they serve from their positions of privilege is a curious and contentious question.

The disaggregated narratives of human rights struggles on the nightly news apparently lave not been sufficient for soine legal academics. They want documented accounts denionstrating the efficacy of rights discourse and storytelling in the social inovements of outsider groups. Einpirical evidence of the traditions, histories, and lives of oppressed peoples actually transforming legal thought and doctrine about rights could then be used to cure skeptics of the critical race scholarly enterprise. ${ }^{3}$ "See here," the still unconverted in the faculty lounge can be told, "this stuff works, if applied and systenratized correctly."

Despite the attacks from society's dominant groups in the legal academic spectrum - both the left and right-the voices of legal scholars of color have sought to keep faitli with the struggles and aspirations of oppressed peoples around the world. These emerging voices recoginze that now is the time to intensify the struggle for human riglits on all frontsto heighten deniands, engage in intense political rhetoric, and sharpen critical thinking about all aspects of legal thouglt and doctrine.

The rapid emergence of indigenous peoples' human rights as a subject of inajor concern and action in contemporary international law provides a umque opportumity to witness the application of rights discourse and storytelling in institutionalized, law-bound settings around the

2. See, eg., Kennedy, Racial Critiques of Legal Academia, 102 HaRv. L. REv. 1745 (1989). This article, by Professor Randall Kennedy, challenges the view "that some members of marginalized groups, by virtue of their marginal status, are able to tell stories different from the ones legal scholars usually hear," or that such stories reveal new types of valuable knowledge about the world that ought to be known. Delgado, When A Story is Just a Story: Does Voice Really Matter?, 76 VA. L. REv. 95, 95 (1990). Kennedy, a scholar of color, has drawn a great deal of attention for his article and his views. See, eg., Wiener, Law Profs Fight the Power, NAtion, Sept. 4, 1989, at 246. In a New York Times article containing a three column picture of the African-American Harvard law school professor at his desk, Kennedy was defended by "a white professor, speaking on condition of anonymity," who asserted the existence of "a sort of 'lynch Randy Kennedy' mind-set." Rothfeld, Controversy Over Minority Writing, N.Y. Times, Jan. 5, 1990, at B6, col. 3.

3. On critieal race theory and scholarship, see Delgado, supra note 2, at 103 (noting that critical race theorists are impatient with the dominant discourse of liberal legalism and its outlook of "[p]atience, vigilance, hiberal legalism and measured progress" regarding civil rights and race relations). 


\section{world. ${ }^{4}$ By telling their own stories in recognized and authoritative in-}

4. There is, as Professor Hurst Hannum explains, no "commonly accepted definition of the term 'indigenous' in contemporary international law discourse." Hannum, New Developments in Indigenous Rights, 28 VA. J. INT'L L. 649 (1988). For the leading United Nations Study on Indigenous Populatious, see J. CoBo, Study of THE PRoblem of Discrimination against IndigeNOus PopUlations, U.N. Doc. E/CN.4/Sub.2/1986/7/Add.4, U.N. Sales No. E.86.XIV.3 (1986) [hereinafter UN INDIGENOuS STUDY]. This study attempts to distinguish Indigenous Populations from other minority groups by the following definition:

378. Indigenous populatious may, therefore, be defined as follows for the purposes of international action that may be taken affecting their future existence:

379. Indigenous communities, peoples and nations are those which, having a historical continuity with pre-invasion and pre-colonial societies that developed on their territories, consider themselves distinct froni other sectors of the societies now prevailing in those territories, or parts of then. They form at present nondominant sectors of society and are determined to preserve, develop and transmit to future generations their ancestral territories, and their ethnic identity, as the basis of their continued existence as peoples, in accordance with their own cnltural patterns, social institutious and legal systems.

380. This historical continuity may consist of the continuation, for an extended period reaching into the present, of one or more of the following factors:

(a) Oceupation of ancestral lands, or at least of part of them;

(b) Common ancestry with the original occupants of these lands;

(c) Culture in geueral, or in specific manifestations (such as rehigion, living under a tribal system, menibership of an mdigenous community, dress, means of livelihood, life-style, etc.);

(d) Language (whether used as the ouly language, as mother-tongue, as the habitual means of communication at hoine or in the family, or as the main, preferred, habitual, general or normal language);

(e) Residence in certain parts of the country, or in certain regions of the world;

$(f)$ Other relevant factors.

381. On an individnal basis, an indigenous person is one who belongs to these indigenous populations through self-identification as imdigenous (group consciousness) and is recognized and accepted by these populations as one of its meinbers (acceptance by the group). 382. This preserves for these communities the sovereign right and power to decide who belongs to them, without external interference. Id. at 4 .

Such efforts at a formal definition liave not been generally accepted by indigenous peoples and their advocates who participate in the international human rights standard-setting process. Generally, indigenous peoples lave insisted on the right to define theinselves.

For purposes of this Article, "indigenous" peoples are those groups colonized by Western and other settler states and who have lost their sovereignty while maintaining a distinct cultural identity. Indigenous peoples usually seck to sustain their distinct cultural identity in intimate relation with their traditionally-occupied territories. The best evidence of this distinct cultural identity results from indigenous peoples identifying themselves as such.

The sudden emergence of indigenous peoples' hunan rights in international law is docuniented in official texts of the international legal system, most notably and recently by the June 1989 adoption of Convention 169 on Indigenous and Tribal Peoples by the International Labor Organization (ILO), a specialized agency of the Umited Nations. The proposed Convention 169, now open for immediate ratification by ILO meinber states, revises the 1957 ILO Convention No. 107 on the Protection and Integration of Indigenous and other Tribal and Semi-Tribal Populations in Independent Countries. INT'L LABOUR ORG., CONVENTIONS AND RECOMMENDATIONS ADOPTED BY THE INTERNATIONAL LABOUR CONFERENCE, 1919-66, at 901-15 (1966).

Convention 107 was the only previously existing imternational legal imstrument directly addressed to questions of indigenous peoples' rights. Its uutegratiomst approach to indigenous rights issues was widely criticized and rejected by indigenous advocacy groups in the 1970s and 1980s, leading to its revision and adoption of the uew Convention 169 by the ILO in June 1989. See INT'L

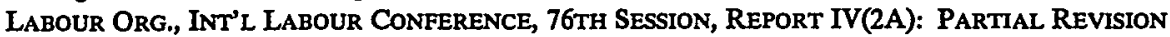
of THE INDIgenous AND TRIBAL Populations CoNVENTION, 1957 (No. 107) (1989). More conl- 
ternational human rights standard-setting bodies during the past decade, indigenous peoples have sought to redefine the terms of their right to survival under international law. 5

Under present, Western-dominated conceptions of international law, indigenous peoples are regarded as subjects of the exclusive doinestic jurisdiction of the settler state regimes that invaded their territories and established hegemony during prior colonial eras. ${ }^{6}$ At present, international law does not contest unilateral assertions of state sovereignty that limit, or completely deny the collective cultural rights of indigenous peoples. ${ }^{7}$ Contemporary international law also does not concern itself with protecting indigenous peoples' traditionally-occupied territories from uncompensated state appropriation, even when indigenous territories are secured through treaties with a state. According to contemporary international discourse, such treaties should be treated as legal

prehensive treatment of Convention 107 and the ILO revision process can be found in Berman, The International Labour Organization and Indigenous Peoples: Revision of I.L.O. Convention No. 107 at the 75th Session of the Intemational Labour Conference, 1988, 41 INT'L COMM'N JURISTs REV. 48 (1988).

The field of indigenous rights in international law is itself undergoing a scliolarly renaissance. Gordon Bennett's ABoriginal Rights IN INTERNATional LAw (Occasional Paper No. 37 of the Royal Anthropological Inst. of Gr. Brit. and Ir., 1978), was one inportant work signaling increased interest among Western legal scholars in questions of fnndamental justice for indigenous peoples under international law. Russell Lawrence Barsh and Douglas Sanders, both prolific scholars and long-time indigenous human rights advocates, did much to sustain serious consideration on this topic in the North American legal literature throughout the 1980s. See, e.g., Barsh, Current Developments: Indigenous Peoples: An Emerging Object of International Law, 80 AM. J. INT'L L. 369 (1986) [hereinafter Barsh, Emerging Object] (discussing international concern about the rights of indigenous peoples with special attention to the UN activity); Barsh, Indigenous North America and Contemporary International Law, 62 OR. L. REv. 73 (1983) [hereinafter Barsh, Indigenous North America] (tracing the developinent of international hunan rights law respecting indigenous peoples and arguing that real progress has occurred only in the last 20 years with the coining of UN involvement); Sanders, The Re-Emergence of Indigenous Questions in International Law, in CANADIAN HUMAN RIGHTS YearbooK No. 3 (1983) (describing indigenous rights movements that have fought for legal rights in international forums in the 19th and 20th centuries).

Today, an international community of indigenous and non-indigenous legal and interdisciplinary scholars generates a lively literature coinprising the feld of indigenous rights in international law. See Roy \& Alfredsson, Indigenous Rights: The Literature Explosion, 13 TRANSNAT'L PERSPECTIVES 19 (1987). Major figures of contemporary international law scholarship have now focused their attention on indigenous rights questions. See, e.g., Falk, The Rights of Peoples (In Particular Indigenous Peoples), in The RIGHTS of PeOples 17 (J. Crawford ed. 1988) (discusses the statist concept of human rights, concluding that new approach needed to adequately protect indigenous peoples' basic rights); see also Hannum, supra, at 649 (discussing UN interest in human rights of indigenous peoples historically and comments on current trends).

The lruman rights group Cultural Survival has published a collection of essays offering valuable interdisciplinary perspectives and a comprehensive bibliography on indigenous human rights issues. See Human Rights AND ANTHRopology (T. Downing \& G. Kusliner eds. 1988).

5. See infra text accompanying notes 67-79.

6. See infra text accoinpanying notes 37-52.

7. See infra text accompanying notes 50-52. 
nullities. ${ }^{8}$ Finally, modern international law refuses to recognize indigenous peoples as "peoples," entitled to rights of self-determination as specified in United Nations and other n1ajor international human rights legal instruments. ${ }^{9}$

Since the 1970s, in international human rights forums around the world, indigenous peoples have contested the international legal system's continued acquiescence to the assertions of exclusive state sovereignty and jurisdiction over the terms of their survival. Pushed to the brink of extinction by state-sanctioned policies of genocide and ethnocide, indigenous peoples have deinanded heightened international concern and legal protection for their continued survival. ${ }^{10}$

The emergence of indigenous rights in contemporary international legal discourse is a direct response to the consciousness-raising efforts of indigenous peoples in international human rights forums. Specialized international and regional bodies, non-goverumental organizations (NGOs), and advocacy groups are now devoting greater attention to indigenous human rights concerns. ${ }^{11}$ By far the most important of these specialized initiatives to emerge out of the indigenous human rights movement is the United Nations Working Group on Indigenous Populations (Working Group). The Working Group is composed of five international legal experts drawn from the Umited Nations Sub-Commission on the Prevention of Discrimination and Protection of Minorities. The Working Group was created by the Sub-Commission's parent body, the United Nations Econormic and Social Council (ECOSOC) in 1982 and given a specific mandate to develop international legal standards for the protection of indigenous peoples' human rights. ${ }^{12}$

The Working Group, at its 1989 session at the United Nations Commission on Human Rights in Geneva, Switzerland, presented a First Revised Text of a Draft Universal Declaration on Rights of Indigenous Peoples. ${ }^{13}$ This Draft Declaration is being prepared by the Working Group for imitial approval by the ECOSOC subsidiary bodies and for

8. See infra text accompanying notes 126-30.

9. See infra text accompanying notes 108-21.

10. See infra text accompanying notes 122-34.

11. See Hannum, supra note 4, at 652-54 (describing various specialized international agencies and groups devoted to indigenous rights concerns).

12. See infra text accoinpanying notes 54-59.

13. Discrimination Against Indigenous Peoples: First Revised Text of the Draft Universal Declaration on Rights of Indigenous Peoples, U.N. Doc. E/CN.4/Sub.2/1989/33 (1989) [hereinafter WG Draft] (prepared by the Chairman-Rapporteur of the Working Group on Indigenous Populations, Mrs. Erica-Irene Daes). During its 1990 session, the Working Group continued discussion on the Draft Universal Declaration released in 1989. It is expected that the suggested amendments raised and presented at the 1990 session will be considered by Mrs. Daes for incorporation in a Sccond Revised Text, expected to be released at the 1991 Working Group Session. 
ultimate ratification by the Umited Nations General Assembly as an international human rights instrument exclusively devoted to the protection of indigenous peoples' survival.

In its present form, the Working Group's Draft Universal Declaration would dramatically expand international legal protection for indigenous peoples' human rights. ${ }^{14}$ The Draft therefore represents one of the most significant by-products of indigenous involvement in the international human rights process during the past decade. This Article describes the central role of indigenous peoples' own stories in the Working Group's efforts toward developnient of an internationally recognized legal instrument declaring the human rights of indigenous peoples.

For the skeptical and uninitiated, Part I of the Article offers a brief, introductory account of how the international human rights legal process is understood to work by scholars, experts, and other close observers of the international legal systeni's authoritative niodes of decisionmaking and enforcement of human rights values. ${ }^{15}$ Part II then provides a general account of the historical treatment of indigenous tribal peoples' status and rights under the doctrine of discovery and related primciples in international law. ${ }^{16}$ Chief Justice John Marshall of the United States Supreme Court propounded the most influential formulation of the European, colonial-era-derived discovery doctrine in international law. According to Marshall's 1823 opimon for a unanimous Court in Johnson v. M'Intosh, 17 the discovery of territory occupied by American Indian tribes in the New World gave the discovering European nation "an exclusive right to extinguish the Indian title of occupancy, either by purchase or conquest."18 This legal practice of denying native tribes full title or sovereign rights in the territories they occupied was adopted by Spaim, Great Britain, and all the major European colonizinig nations as the law of "civilized" nations in their dealings with imdigenous peoples whose territories they invaded.19

14. See infra text accompanying notes $131-40$.

15. For an example of legal academic skepticism of the international human rights process as it might relate to the rights of indigenous peoples, see Laurence, Learning to Live With the Plenary Power of Congress Over The Indian Nations, 30 ARIZ. L. REv. 413, 429-30 (1988). In this article, Professor Laurence, in response to my advocation of broadened access for indigenous peoples in international legal forums, see $\mathrm{R}$. Williams, The Algebra of Federal Indian Law: The Hard Trall of Decolonizing and Americanizing the White Man's Indian Jurisprudence, 1986 WIS. L. REv. 219, 29399, declared that he has "little faith in the ability of public international law to protect any valuable rights. I have no faith in the ability of public international law to put bread on American Indian tables." Laurence, supra, at 428.

16. See infra text accompanying notes $37-52$.

17. 21 U.S. (8 Wheat.) 543 (1823).

18. Id. at 573.

19. See infra text accompanying notes $46-52$. 
The United States and other Western settler states formally adopted the colonial principles supporting the doctrine of discovery as outlined by Justice Marshall in Johnson as part of their donnestic law of indigenous peoples' rights and status.20 European and other Western writers on international law in the 19th century regarded this "custoniary" practice of Western colonizing nations as demonstrating the general acceptance of denying indigenous peoples' territorial rights and equal sovereignty as part of the "civilized" world's law of nations. This conception of indigenous peoples' diminished rights and status derived fronı the doctrine of discovery, still retains valuable currency in international legal discourse today. 21

The stories told by indigenous peoples and their advocates to international human rights forums during the past decade have sought to devalue the legitimacy of legal principles derived froin the doctrine of discovery, which denies indigenous peoples' rights and status in imternational law. Part III of this Article discusses the emergence of indigenous human rights in contemporary international legal discourse. ${ }^{22}$ Indigenous peoples have sought to raise consciousness about the failures of settler state regimes throughout the world to protect the survival of nidigenous peoples by presenting their stories to international human rights bodies such as the Working Group. In challenging the exclusive jurisdictional claims of settler state governments to define the terms of their survival in the world, indigenous peoples have given voice to a new vision of the human rights that matter to them under international law. This vision seeks international legal recognition of indigenous peoples' collective human rights to exist as culturally autonomous peoples, to contimue in the peaceful possession of their traditionally occupied territories, and to exercise greater self-determining autonony over their ways of life. ${ }^{23}$

Part IV of this Article analyzes the Working Group's Draft Universal Declaration on Rights of Indigenous Peoples. ${ }^{24}$ The Working Group's Draft Declaration represents a formal response to indigenous peoples' concerns by one important recognized standard-setting body im the international human rights legal process. Because a Universal Declaration on Indigenous Rights would seek to assume the same authoritative and nonnative role in the international legal systenı presently filled by other international human rights instruments, the Working Group Draft

\footnotetext{
20. See infra text accompanying notes $37-45$.

21. See infra text accompanying notes $46-49$ \& 122-30.

22. See infra text accompanying notes 53-69.

23. See infra text accompanying notes 68-69.

24. See WG Draft, supra note 13. See also infra text accompanying notes 70-134.
} 
provides one important ineasure of the power of indigenous peoples' own stories to transforn legal thought and doctrine about the rights that matter to thein.

The Article concludes in Part V by offering soine reflections on the einergence of indigenous rights in international law and the efficacy of rights discourse and consciousness-raising through narrative for oppressed groups. Several critical race theorists, most notably Professor Richard Delgado, have argued that dispute resolution forums seeking to constrain bias and prejudice through fornal rules and procedures inay be more likely to achieve substantive justice for outsider groups. ${ }^{25}$ This thesis is explored in the context of the Working Group's standard-setting activities in order to develop a better understanding of the importance of fairness and fornality for the efficacy of rights discourse and consciousness-raising through narrative in the struggles of peoples of color. ${ }^{26}$

\section{INDIGENOUS RightS AS HUMAN RightS IN THE INTERNATIONAL LEGAL SYSTEM ${ }^{27}$}

What explains the sudden einergence of indigenous rights in international human rights law and discourse during the past decade? ${ }^{28}$ Why have so inany indigenous peoples and their advocates turned to international human rights forums for redress of their grievances against settler State governments? When so much work needs to be done to transform the domestic laws of states that exercise jurisdiction and power over the terins of their survival in the world, why have indigenous peoples placed such great faith and efforts in the international human rights process?

Like inany other oppressed peoples who have appealed to the emerging discourse of international human rights in recent years, indigenous peoples recognize that international human rights law and norms

25. See, e.g., Delgado, Dunn, Brown, Lee \& Hubbert, Fairness and Formality: Mininizing the Risk of Prejudice in Alternative Dispute Resolution, 1985 WIS. L. REv. 1359 [hereinafter Delgado \& Dunn, Minimizing Risk]; Delgado, ADR and the Dispossessed: Recent Books About the Deformalization Movement (Book Review), 13 LAW \& Soc. INQUIRY 145 (1988).

26. See infra text accompanying notes 135-55.

27. There is a vast, scholarly hiterature on the international human rights process and how it works. Deserving special mention is 1 HUMAN RIGHTS IN INTERNATIONAL LAW: LEGAL AND PoLICY IsSUES (T. Meron ed. 1984) [hereinafter HUMAN RIGHTS], a collection of essays that covers the principal human rights areas and provides an excellent starting point for law students and scholars interested in understanding the international human rights process. For a provocative and stimulating effort at a theoretical systematization of the field, see M. MCDoUGAL, H. LASSWELL \& L. Chen, human Rights and World Public Order: The Basic Policies of an INTERNATIONAI LAW OF HUMAN DIGNITY (1980). See also HUMAN RIGHTS IN THE WORLD COMMUNITY: IsSUES AND ACTION (R. Claude \& B. Weston eds. 1989); New DiRECTIONS IN Human Rights (E. Lutz, H. Hunnum \& K. Burke eds. 1989); V. VAN DYKe, HumaN Rights, ETHNICITY, AND DISCRIMINATION (1985).

28. See, e.g., sources cited in supra note 4. 
have come to assume a more authoritative and even constraining role on state actors in the world. ${ }^{29}$ Government assertions in the international community that abuses of its citizens' human rights are matters of exclusive doniestic concern have become more difficult to sustain. Various formal and informal inechanisms have proven capable of ameliorating abusive state practices violative of international human rights instrnments and standards. Wanton state violators of international legal norms often pay the price of increasing isolation. Vitally important economic and cultural exchange opportunities often are constricted by the international community in reaction to a sovereign state's human rights abuses of its citizens. Altliougli state responses to pressure froin the international human rights process may not always be sincere or even sustained over time, experience indicates that few governments actively desire pariah status im the international community. ${ }^{30}$

What indigenous peoples have souglit to achieve in the international human rights process during the past decade is to transform the present conceptions about indigenous riglits that dommate the international legal system. Seeking to reverse the controlling assumption that indigenous peoples are not proper legal subjects of international concern or sanction, a primary goal of indigenous advocates has been to create a formal international legal declaration of indigenous rights. Such a declaration would recognize those rights tliat matter to the survival of indigenous peoples that are not currently recognized or adequately protected by the legal systems of settler states. ${ }^{31}$

The UN General Assembly's adoption of a Universal Declaration on Rights of Indigenous Peoples is one important goal of a broad-based movenient to transform legal thought and doctrime about indigenous

29. See INDEPENDENT COMMISSION ON INTERNATIONAL HuMANITARIAN ISSUES, INDIGENous Peoples: A Global Quest for Justice (1987) [hereinafter Global Quest]. The Independent Commission on International Humanitarian Issues in assessing the future rule of human rights organizations stated that:

In the coming years international and non-governmental [human rights] organizations are

likely to have a critical impact on the aspirations of indigenous peoples. They represent to a great extent the inoral consciousness of the world. Their actions can create a favorable climate for governments to include indigenous peoples among their priorities. Solne have done pioneering work in focusing international attention on thein.

Id. at 115. See generally Alfredsson, International Law, International Organizations and Indigenous Peoples, 36 J. INT'L AFF. 113 (1982) (discussing the emergence of indigenous peoples' concerns in the international human rights legal system).

30. See M. McDougal, H. Lasswell \& L. Chen, supra note 27, at 313-60 (describing and analyzing the various modes of authoritative decision processes for enforcing human rights prescriptions).

31. See Barsh, Emerging Object, supra note 4, at 378-83 (describing indigenous advocacy and state recognition of the need for a special legal instrument on indigenous human rights that goes beyond existing international norms of human rights). 
rights in international and domestic arenas. ${ }^{32}$ Through appeals to the broadly-stated standards and values contained in the huinan rights declarations and instruinents adopted by the UN General Assembly, the global human rights process has demonstrated its efficacy despite its admittedly weak formal sanctioning and enforceinent mechanisms. Moral suasion, shaine, and the simple capacity to appeal to an internationally recognized legal standard for hunian rights have all done much to undermine the legitimacy of state-sanctioned doinestic practices that deny human rights. Hunian rights values have been secured through the international legal process in a number of domestic political and legal systems. ${ }^{33}$ There is reason to hope for similar domestic effects once the standards enunciated in a Umiversal Declaration on Rights of Indigenous Peoples enter the official legal discourse of the international huinan rights process.

Particularly with respect to the donestic legal systems of the Westeru settler states, the emerging international legal discourse of indigenous human rights holds significant transformative potential. Many of the Western settler state governments actively have advocated international acceptance of the norms and primciples embodied in existing international human rights instruments. ${ }^{34}$ The United States, for example, has a poor record of formal ratification of hunan rights instruments. But the Umited States government nonetheless has proved capable of aggressive and at times even effective advocacy of human rights standards in international relations with East Bloc and Third World nations. ${ }^{35}$ Whether increases in the respect for human rights in those countries represents a response to abstractly stated human values or to the calculated diniensions of global power pohtics is largely an academic's question. The international human rights process rehes on both forms of persuasion in achieving its sometimes considerable synergistic effectiveness. The dis-

32. See Global QUEST, supra note 29, at 31-131.

33. See, e.g., id. at 109-31 (describing the efforts of the World Bank, International Labour Organization, and UN bodies to protect indigenous people and suggestions for further protection); M. MCDougal, H. LASSwell \& L. CHEN, supra note 27, at 313-60 (discussing the impact of international human rights standards on state actors).

34. See, e.g., Meron, Teaching Human Rights: An Overview, in Human RighTs, supra note 27, at 1, 11-24 (arguing that hnman rights are relevant to university stndents; one principal reason is that Western nations claim to value human rights and have made this their public position at the U.N.).

35. See Foreign Affairs and Nat'l Defense Division, Congressional Research SerVICE, LIBRARY OF CONGRESS, 96TH CONG., 15T SESS., HuMAN RIGHTS AND U.S. FOREIGN AsSISTANCE: EXPERIENCES AND Issues IN Policy IMPLEMENTATION (1977-78) 5 (Comm. Print 1979) (finding that "U.S. pohicy has sensitized foreigu governments to human rights issues and has been a contributing factor in many situations where conditions have improved."). See generally Meron, supra note 34, at 18-24 (discussing status and acceptance of human rights standards internationally). 
course of human rights is intended to transform moral and institutional patterns of thought and action.

Such strategic factors, therefore, suggest that a nnajor goal for indigenous rights advocates in the Western settler states must be to use a Universal Declaration on Rights of Indigenous Peoples, in whatever form it emerges from the human rights standard-setting process, to transform the perception of the Western settler state governments that human rights only amount to a foreign policy concern. The standards and principles declared in a Universal Declaration on Rights of Indigenous Peoples inust enter into the domestic policy discourse of these states as an urgent matter affecting their own moral standing and authority in the international community as progressive advocates of international human rights standards and values.

It is worth noting, in fact, that in the sessions of the Working Group and other imternational human rights forums, the governments of the United States, Australia, and New Zealand-all of which possess exen1plary reputations for protecting individual human rights within their domestic legal systems-are among the niost frequently cited violators of indigenous peoples' human rights. For indigenous peoples colonized by those countries in particnlar, the ability to appeal to a differently inflected legitimating discourse contained in a Universal Declaration on Rights of Indigenous Peoples could contribute significantly to transforming the domestic legal systems of those countries toward the goal of protecting imdigenous peoples. The Declaration would provide indigenous peoples, at least in the nore progressive Western states, with opportunities hiterally to redefine the terms of their survival. And given that these more progressive Western states consistently have demonstrated a willingness to advocate internationally those human rights standards that they have adopted as their own state practices, there is reason also to hope for the progressive advancement of indigenous human rights in countries less committed to assuring indigenous survival. Just as the civil rights movement in the United States, with its emphases on minority rights and facilitating freedoms of speech and protest, contributed significantly to the promotion and recognition of individual human rights internationally, ${ }^{36}$ the emerging discourse of indigenous human rights holds the potential for transforming legal thought and doctrime in a similar,

36. See Henkin, Rights: American and Human, 79 ColUM. L. REV. 405 (1979). Louis Henkin assessed the American contribution to the international recognition of human rights in the following fashion:

Americans were prominent among the architects and builders of international human rights, and American constitutionalism was a principal inspiration and inodel for them. As a result, most of the Umiversal Declaration of Human Rights, and later the International 
progressive global fashion. Legitimation and acceptance of this new human rights discourse in the domestic law of Western states that traditionally have exercised inoral leadership and authority in the international human rights process can lead to acceptance of indigenous rights in countries less alert to the importance of vigorously protecting human rights as defined by international standard-setting activities.

\section{INDIGENOUS RIGHTS IN INTERNATIONAL LAW: INDIGENOUS RIGHTS UNDER THE DOCTRINE OF DISCOVERY}

Why is it that modern international law demes whatever modest protections it might provide to indigenous peoples and their continued survival? Why does the international legal system regard the cultural survival, territorial integrity, and self-determining autonomy of indigenous peoples as matters within the exclusive jurisdiction of the settler state regimes that invaded and subjugated them?

The present dominant conceptions of indigenous rights in international law largely derive from principles associated with the European doctrine of discovery. ${ }^{37}$ For five hundred years, this doctrine and its discourse of diminished indigenous legal status and rights has been relied on by European and European-derived settler states to regulate and legitimate their colomial activities in indigenous peoples' territories. ${ }^{38}$ The most famous and influential elaboration of this doctrine in international law is Chief Justice John Marshall's opinion for the United States Supreme Court in the 1823 case, Johnson v. M'Intosh. ${ }^{39}$ In Johnson, the

Covenant on Civil and Political Rights, are in their essence American constitutional rights projected around the world.

Id. at 415 (citations omitted).

Professor Mary Dudziak las demonstrated in an enlightening fashion the reciprocal influence of the early international luman rights movement on the United States Civil Rights era. Dudziak, Desegregation as a Cold War Imperative, 41 STAN. L. Rev. 61 (1988).

37. I discuss at length the emergence and descent of the doctrine of discovery in contemporary international and doinestic legal thought and doctrine in R. WILLIAMS, THE AMERICAN INDIAN IN Western Legal Thought: The Discourses of Conquest (1990). See also Berman, The Concept of Aboriginal Rights in the Early Legal History of the United States, 27 Bufpalo L. REv. 637 (1979) (discussing the doctrine's genealogy in United States federal Indian law); R. Williams, supra note 15, at 226-65 (discussing doctrine's legacy in nodern federal Indian law and international law).

38. See, e.g., sources cited in supra note 4.

39. 21 U.S. (8 Wheat.) 543 (1823). Johnson's genealogy as a constitutive text of the custonary international law of the Western world regarding indigenous rights can be traced in the following domestic law judicial decisions: Calder v. Attorney General of British Columbia, 34 D.L.R.3d 145 (1973) (Canada); In re Southem Rhodesia [1919] App. Cas. 211 (P.C. 1918); St. Catherine's Milling and Lumber Co. v. The Quecn, 13 S.C.R. 577 (1887) (Canada); Regina v. Symonds, 1847 N.Z.P.C.C. 387 (New Zealand). Professor Robert Clinton has written an excellent study on the development of "Indian title" theory in English-speaking settler states. See Clinton, The Proclamation of 1763: Colonial Prelude to Two Centuries of Federal-State Conflict Over the Management of Indian Affairs, 69 B.U.L. REV. 329 (1989). 
Supreme Court held that under principles derived from Europe's law of nations, the discovery of territory occupied by Indian tribes in the New World gave to the discovering European nation "an exclusive right to extinguish the Indian title of occupancy, either by purchase or conquest." 40

"The character and religion" of the indigenous peoples of the New World, Marshall explained in Johnson, "afforded an apology for considering them as a people over whom the superior geinus of Europe might claim an ascendancy." 41 Under this doctrine of discovery, the American Indians" "rights to complete sovereignty, as independent nations, were necessarily diminished, and their power to dispose of the soil at their own will, to whomsoever they pleased, was demed."42 Under the Europeans' rule of international law, Marshall declared, the discovery of indigenous territory gave an "exclusive title" to the European discoverers of the New World. ${ }^{43}$

Marshall further explained in Johnson that once indigenous tribes were "discovered," they became the "exclusive" concern of their discovering European nation. Spain, Great Britain, and the other colonizing states of Europe all had claimed and exercised superior sovereign rights to imdigenous territories in the New World under the doctrine's jurisdictional principles. ${ }^{44}$ And also, by Marshall's opinion for the Supreme Court in Johnson v. M'Intosh, the doctrine of discovery was incorporated forinally into the domestic law of the United States. ${ }^{45}$

The century-long era of Western global expansion following Marshall's 1823 opinion in Johnson significantly extended and refined the scope of apphication of the doctrine of discovery. The Western writers and theorists who dominated international law during this era interpreted the doctrine's widespread reception in the domestic law of European-derived settler states as evidence of the principles of a customary law of all "civilized" nations in dealing with indigenous peoples. ${ }^{46}$ Their

40. Johnson, 21 U.S. (8 Wheat.) at 587.

41. Id. at 573. On the development of this central idea of Western colonial legal thought that the American Indian's normative divergence justified European conquests in the New World, see generally R. WILLIAMS, supra note 37.

42. Johnson, 21 U.S. (8 Wheat.) at 589.

43. Id. at 574 .

44. Id. at 595-97. See generally R. WILliams, supra note 37, at 325-28 (discussing the emergence and descent of the doctrine of discovery in contemporary international and domestic legal thought and doctrine).

45. R. WILliams, supra note 37 , at $308-17$.

46. The influence of the Western "positivist" writers who dominated international law in the late 19th and early 20th centuries and their interpretatious of indigenous rights in the field they dominated are more thoroughly discussed in Anaya, The Rights of Indigenous Peoples and International Law in Historical and Contemporary Perspective, in HARVARD INDIAN LAW SYMPOSIUM 191 
books and treatises asserted that the only territorial titles recognized by international law are the titles held by "civilized" meınbers of the family of Western nations. ${ }^{47}$ These writers did not regard imdigenous peoples

(1989) (discussing the imconsistency between natural rights tradition in the West and the treatment of native peoples under international law); Barsh, Indigenous North America, supra note 4, at 74-80 (discussing colonial powers territorial expansion for "good of natives" from 1880s to $1930 \mathrm{~s}$ and the development of notion of "trusteeship"); Hackshaw, Nineteenth Century Notions of Aboriginal Title and their Influence on the Interpretation of the Treaty of Waitangi, in WAITANGI: MORI \& PKEH,

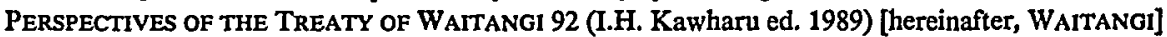
(states make international law through practice rather than through discovery of existing rules of natural law; in New Zealand, positivist law required a European-style government to establish title to land recognized by the Crown); National Indian Youth Council, The Rights and Status of Indigenous Peoples Under International Law During the Classical Era Treaty Period, 1600-1840 (prepared and submitted by $\mathbf{R}$. Williams to the United Nations Working Group on Indigenous Populations, Seventh Session, July 31-August 4, 1989, Geneva, Switzerland).

47. See generally C. HYDE, 1 INTERNATIONAL LAW CHIEFLY AS INTERPRETED AND APPLIED BY THE UNITED STATES 320-30 (1945) ("IT]he thought early obtained, at least with respect to the western hemisphere, that the native inhabitants possessed no rights of territorial control such as could be assimilated to a right of sovereignty which a European monarch was bound to respect."). Id. at 328. Similar viewpoints ean be found stated in a number of leading treatises of the period. See, e.g., L. OpPENheim, InTERNATIONAL LAw 383-84 (R. Roxburg 3d ed. 1920) ("[O]nly such territory may be the object of occupation as is no state's land, whether entirely uninhabited, as e.g. an island, or inhabited by natives whose community is not to be considered as a state."); J. WestLake, Chapters on the Principles of International Law 137-40 (1894) ("Occupation by uncivilised tribes of a tract ... was not felt to interpose a serious obstacle to the right of the first civilised occupant.").

British publicist John Westlake was perhaps one of the most infiuential international legal theorists of the late 19th century to write on the topic of indigenous rights under then current positivistinspired views of international law. In his widely-disseminated CHAPTERS ON THE PRINCIPLES OP INTERNATIONAL LAW, supra, Westlake distinguished between "civilized and uncivilized humanity." International law and society were concerned only with relations between "civilized" statesi.e., those with European state-forms of government. See id. at 136-38. As for the international legal status of indigenous peoples, Westlake had this to say:

When people of European race come into contact with American or African tribes, the prime necessity is a government under the protcction of which the former [European race] niay carry on the complex life to which they have been accustomed in their hoines.... and which inay proteet the natives in the enjoyinent of a security and well-being at least not less than they enjoyed before the arrival of the strangers. Can the natives furnish sueh a governnent, or can it be looked for from the Europeans alone? In the answer to that question hies, for international law, the difference between civilisation and want of it.... The infiow of the white race cannot be stopped where there is land to cultivate, ore to be nined, commerce to be developed, sport to enjoy, curiosity to be satisfied. If any fanatical admirer of savage life argned that the whites ought to be kept out, he would only be driven to the same conclusion by another route, for a governinent on the spot would be necessary to keep him out. Accordingly, international law has to treat such natives as uncivilised.

Id. at 141-43.

Lassa Oppenheim, another well-respected and widely-published international law scholar of this era, specified:

[T]hree conditions for the admission of new inenibers into the circle of the Family of Nations. A State to be adinitted must, first, be a civilised State which is in constant intercourse with meinbers of the Family of Nations. Such state must, secondly, expressly or tacitly consent to be bound for its future international conduct by the rules of International Law. And, thirdly, those States which have hitherto formed the Fannily of Nations inust expressly or tacitly consent to the reception of the new ineinber.

L. OPPENHEIM, supra, at 32. 
living under a "backwards" tribal organization as members of that select group of states. ${ }^{48}$ Therefore, they concluded, for purposes of international law, indigenously occupied territories can be regarded as terra nullius - that is, as lands without a recognized owner and available for occupation by a civilized meinber of the Western family of nations. ${ }^{49}$

Significantly extending the principles of the doctrine of discovery as first elaborated by Marshall, the dominant discourse of Western international lawyers and theorists of this era denied effective rights of self-determination to indigenous peoples. "Civilized" states pursued a sacred duty of trust by dismantling "tribal organization" and treating indigenous peoples "as individuals under guardianship."so

Through the preachings of these Western theorists, indigenous peoples were effectively dismissed as subjects of concern in international legal discourse. ${ }^{51}$ Indigenous territories were regarded as vacant and appropriable by a "civilized" Western state. Indigenous peoples did not possess internationally recognizable rights of self-determination. They

48. See, eg., M. LINDLEY, The ACQuisition AND GovernMENT OF BACKWARd Territory IN INTERNATIONAL LAW 17-23 (1926) (discussing the views of those who do not consider the limited degree of sovereignty that might be possessed by "backwards" peoples a bar to occupation of those peoples' lands); J. WESTLAKE, supra note 47, at 141-43 ("natives" incapable of furnishing government sufficiently "civilised" to merit recognitiou by "family of uations").

49. See C. HYDE, supra note 47, at 175 ("If the inhabitants of the territory concerned are an uncivilized people, deemed to be incapable of possessing a right of property and control, the conqueror inay, in fact, choose to ignore their title, and proceed to occupy the land as though it were vacant."). See also L. OPPENHEIM, supra note 47, at 383-84; J. WESTLAKE, supra note 47, at 15560. A series of infiuential international tribunal awards in the 1920 s and 1930 s affirmed the position of the Western positivists that international law did uot recognize indigenous territorial rights. See Legal Status of E. Greenland (Deu. v. Nor.), 1933 P.C.I.J. (ser. A/B) No. 53 (Apr. 5); Island of Palmas Case (U.S. v. Neth.), 2 R. Int'1 Arb. Awards 829 (1928); Cayuga Iudians (Gr. Brit. v. U.S.), 6 R. Int'l Arb. Awards 173 (1926). The cases are discussed in Anaya, supra note 46, at 208-11. It was not until 1975, in the Western Sahara case, that an international tribunal sought to question the extreme legal positiou that indigenous peoples' lands could be regarded as terra nullius for international law purposes. The International Court of Justice, in an advisory opimion relating to the selfdetermination of the former African colony claimed by Spain, decided that:

Whatever differences of opiniou there may have been among jurists, the State practice of the relevant period indicates that territories inhabited by tribes or peoples having a social and pohitical organization were not regarded as terrae nullius.

Western Sahara (Morocco v. Spain), 1975 I.C.J. 12, 39 (Oct. 16).

50. A. Snow, The Question of Aborigines in the Law and Practice of Nations 55 (1921); see also M. LINDLEY, supra note 48, at 328-30 (discussing theories of civilized nation's sacred duty of trust towards "backward" tribes).

51. According to Westlake, the exclusion of indigenous peoples' rights from the concerns of international law "does not inean that all rights are denied to such natives, but that the appreciation of their rights is left to the conscience of the state within whose recognized territorial sovereignty they are coinprised, the rules of the international society existing ouly for the purposes of regulating the inutual conduct of its meinbers." J. WESTLAKE, supra note 47, at 136. See also G. GoNG, ThE STANDARD OF "Civilization" IN INTERNATIONAI SOCIETy 5463 (1984) (discussiug standards for membership and imclusion in the civilized "family of nations"); L. OPPENHEIM, supra note 47, at 126 (stating that the law of nations does not apply "to organized wandering tribes"). 
were, as one early 20th century Western international tribunal noted, simply "not a legal unit of international law."s2

\section{The EMERgENCE OF INDIGENOUS RightS IN CONTEMPORARY INTERNATIONAL LAW}

Since the 1970s, indigenous groups and their advocates have sought to challenge the continuing dominance in international legal discourse of the doctrine of discovery and its conception of diminished indigenous rights and status. These efforts to transforn international legal thought and doctrine have focused primarily on international hunian rights bodies. The international human rights process provides many and diverse forums for indigenous peoples to engage in open dialogue on the effects of the doctrine of discovery and its related legal principles on indigenous survival. ${ }^{53}$ The highly formalized, standard-setting activities of the huinan rights process have provided a sanctuary for imdigenous peoples to practice their belief that, through their stories, they can raise consciousness and redefine the terns of their own survival in the world.

Without doubt, the inost important forum to emerge out of the indigenous liuman rights movement in contemporary international law is the United Nations Working Group on Indigenous Populations. ${ }^{54}$ The Working Group recently completed its eightl annual session at the United Nations Human Riglts Commission in Geneva, Switzerland in August 1990.55

Created by the United Nations Economic and Social Council (ECOSOC) in 1982, the Working Group is a unique body withm the institutional human rights structure of the Umited Nations. ${ }^{56}$ Its man-

52. Cayuga Indians (Gr. Brit. v. U.S.), 6 R. Int'1 Arb, Awards 173, 174 (1926) (cited and discussed in Barsh, Indigenous North America, supra note 4, at 78-79).

53. See generally sources discussed supra note 27.

54. The emergence of the Working Group as a central focus of indigenous human rights standard-setting activities in the international legal process is described in Hannum, supra note 4, at 66062 ("The Working Group has become the primary focus of international activities by both governinents and non-governmental organizations concerned with indigenous peoples."); see also Alfredsson, Fourth Session of the Working Group on Indigenous Populations, 55 NoRDIC J. INT'L L. 22 (1986); Barsh, Indigenous North America, supra note 4, at 100-102; Barsh, Emerging Object, supra note 4 , at 369 .

55. See Discrimination Against Indigenous Peoples, Report of the Working Group on Indigenous Populations on its Eighth Session, U.N. Doc. E/CN.4/sub.2 1990/42 (report on 1990 progress).

56. In 1971, the UN Sub-Commission on Prevention of Discrimmation and Protection of Minorities appointed Jose R. Martinez Cobo as Special Rapporteur to study the problem of diserimination against indigenous populations. The multi-volume report, completed in 1983, has been a principal vehicle for increased international interest and activity in the indigenous human rights field. See UN INDIGENous STUDY, supra note 4. See generally Hannum, supra note 4, at 658 (discussing the Martinez Cobo Study). The final part of the Study, containing conclusions and recommendations (printed separately) has been cited as an authoritative "reference work of definitive 
date as a forum devoted exclusively to the survival of indigenous peoples includes the urgent task of developing international legal standards for the protection of indigenous peoples' human rights. ${ }^{57}$ Its five inembers are drawn from the select group of international law experts sitting on the United Nations Sub-Commission on the Prevention of Discrimination and Protection of Minorities. With its global agenda and expert membership, the Working Group represents one of the most important initiatives undertaken by the institutional standard-setting inachinery of the international human rights process in recent years. ${ }^{58}$ The Working Group's annual sessions now are attended regularly by nearly four hundred persons, including representatives from over fifty indigenous organizations and observers froin more than two dozen national goveruments. ${ }^{59}$

The Working Group's annual meeting is a highly structured, formal event. The week-long session is chaired by a meinber of the Working Group to whoin all interventions and submissions, written and oral, must be formally directed. The chair's mediatory functions include the inanitenance of strict order and proper decorum throughout the process. Speakers are adinonished to respect time limitations and cumulative or irrelevant interventions oceasionally are ruled to be out of order. The

usefulness," Study of the Problem of Discrimination against Indigenous Populations, U.N. Doc. E/ CN.4/Sub.2/1984/L.41 para. 4. See also Barsh, Emerging Object, supra note 4, at 371 (discussing "authoritative" acceptance of the Martinez Cobo Study).

The Martinez Cobo Study's most important conclusions and recommendations focused on the inadequacy of existing human rights standards in protecting indigenous peoples, the need for a UN sponsored declaration leading to a convention recognizing, among other indigenous human rights, the right to indigenous self-determination and territorial rights, and the proposed establishment of a UN Working Group on Indigenous Populations. 5 UN INDIGENOUS STUDY, supra note 4, at 1-2, originally released as E/CN.4/Sub.2/1983/21/Add.8.

Responding to the Study's recommendations and also to similar recommendations made by a number of indigenous rights organizations at international couferences throughout the late 1970's and early 1980s, the UN Commission on Human Rights (Comm'n Res. 1982/19 [Mar. 10]) and E.S.C. Res. 1982/34, U.N. ESCOR Supp. (No. 1) at 26-27, U.N. Doc. E/1982/82, approved creation of a pre-sessional Working Group on Indigenous Populations of the UN Sub-Commission on Prevention of Discrimination and Protection of Minorities. See Barsh, Emerging Object, supra note 4, at 372; Hannum, supra note 4, at 660 .

57. The Working Group's original mandate directed it to review developments pertaining to the promotion and protection of the human rights of indigenous populations and to develop international legal standards for indigenous human rights. E.S.C. Res. 34, U.N. ESCOR Supp. (No. 1) at 26-27, U.N. Doc. E./1982/82 (1982); Report of the Sub-Commission on Prevention of Discrimination and Protection of Minorities, U.N. Doc. E/CN.4/Sub.2/495 (1981).

58. The five inembers of the Working Group all serve in their individual capacity. Like other subsidiary bodies within the UN, the Working Group's membership is drawn from the regional five groups of Africa, Asia, Latin America, Eastern Europe and the U.S.S.R., and Western Europe and others. See generally Hannum, supra note 4, at 660 (noting that "[in]ost subsidiary bodies such as the Working Group reflect the UN's membership through a practice of proportional representation").

59. Id. 
chair also performs the important role of reminding all attending at the session of the seriousness and importance of the Working Group's standard-setting mandate. Throughout the session, international human rights instruments and other international legal standards, norms, and procedures are frequent topics of discussion and form the backdrop against which the Working Group carries out its mandate. In short, the Working Group has created a serious public space for encounter and dialogue, predominated by the high ideals, public values, and formal diplomacy of the institutionalized imternational human rights standard-setting process. ${ }^{60}$

Within this formal public space, indigenous groups and states are permitted to speak, addressing their concerns directly to the Working Group. The Working Group's sessional agenda permits indigenous liuman rights groups and advocates to make brief, ten-minute oral interventions to the chair. These oral reports also can be supported by written documents submitted before or during the session. The interventions usually describe goverument actions and pohcies affecting indigenous peoples' human rights. The indigenous interventions most frequently detail gross abuses of indigenous peoples' inost basic human rights, invasions of indigenous territories, assaults on cultural survival, and dernal of self-governing autonorny, and typically occupy a large portion of the Working Group's week-long agenda. ${ }^{61}$

States, in turn, are given ainple opportumity to respond to both specific and general indigenous complaints of human rights abuses and also are given an opportunity to outline existing or proposed policy imitiatives and legal developments. Again, the responses are inade directly to the Chair of the Working Group. Notably, even when vehemently denying the aceuracy or bona fides of an indigenous intervention, state representatives usually will couch their replies to the chair in the formalities of diplomatic discourse and appeals to the substantive and procedural norms of the international human rights process and legal system. ${ }^{62}$

60. For a discussion of the implications of the Working Group's formalized standard-setting processes and their role in working to assure fairness for indigenous peoples seeking redress for violations of their luman rights, see infra Part V.

61. Summaries of indigenous interventions regarding governmental actions negatively affecting indigenons peoples' human rights are contained in the Working Group's sessional reports. See, e.g., Report of the Working Group on Indigenous Populations on its Sixth Session, U.N. ESCOR CN.4, U.N. Doc. E/CN.4/Sub.2/1988/24 (1988) [hereinafter cited as W.G. Report, Sixth Session]. Other Working Group Reports are found in U.N. Doc. E/CN.4/Sub.2/1985/22 (1985) (Fourth Session); U.N. Doc. E/CN.4/Sub.2/1984/20 (1984) (Third Session); U.N. Doc. E/CN.4/Sub.2/1983/22 (1983) (Second Session); U.N. Doc. E/CN.4/Sub.2/1982/33 (1982) (First Session).

62. On the implications of these formalized aspects of the Working Group sessions, and their role in assuring fairness to indigenous peoples in the human rights standard-setting process, sce infra Part V. 
In recent years, a final part of the Working Group's sessional agenda has focused increasingly on procedural and substantive aspects of developing a standard-setting international legal instrument for the protection and proinotion of indigenous peoples' human rights. The information gathered through the indigenous oral interventions and state submissions and responses, along with the Working Group meinbers' own considerable expertise in the field of international human rights law, provides the primary inaterial for the Working Group as it fashions its recommended draft text for a Universal Declaration on Rights of Indigenous Peoples. ${ }^{63}$

Despite the highly formalized processes of administermg and investigating its standard-setting inandate, the Working Group has allowed all indigenous peoples who appear before it to tell their stories in terms that are meaningful to their own experiences. Representatives froin groups claiming indigenous status have been permitted to present their oral interventions before the Working Group, constrained only by necessary time limitations and a formal requirement that accusations against a government be presented as factually-based interventions reporting on "developinents" that affect indigenous rights in a particular country. ${ }^{64}$

The highly formalized standard-setting procedures of the Working Group perimit indigenous peoples to tell their stories in terms that are meaningful to thein. At the same time, the Working Group generally has chosen not to constrain the information that can be presented by indigenous peoples during its sessions. Few evidentiary and standing requirements are imposed that work to "screen" information narrowly deeined "relevant" to the Working Group's fact-finding and standardsetting tasks. 65 The "screening function" of the evidentiary and standing

63. For a more thorough discussion of the Draft Declaration, see infra text accompanying notes 72-134.

64. Although some indigenous groups and spokespersous have been less than fully satisfied with the procedures governing their participation at the Working Group, the unprecedented decision to allow wide participation to all groups and individuals claiming indigenous status has been one of the most significant and distinctive features of the Working Group's standard-setting activities. Normally, groups with United Nations recognized formal consultive status are the only non-state actors allowed to present oral and written interventions to a specialized UN body such as the Working Group. See Hannum, supra note 4 at 660-61. Professor Hannum notes that:

As a result of this wide participation, the Working Group has provided a meaningful forum for the exchange of proposals regarding imdigenous rights and for the exposition of indigenous reality throughout the world. While the Working Group reiterates at each session that it is not a "chamber of complaints" and has no authority to hear allegations of human rights violations, it has nevertheless permitted very direct criticisms of government practices by NGO's [non-governmental organizations] as a means of gathering data upon which standards will eventually be based.

Id.

65. The "screcning function" of formal legal standards identified by Delgado and others, see, e.g., Delgado, Storytelling for Oppositionists, supra note 1, at 2441 , is discussed more fully in the context of the Working Group's standard-setting activities, infra text accompanying notes 71-134. 
barriers that sometimes can prove fatal to the claims of oppressed groups has not inhibited the participation of indigenous peoples in the Working Group. ${ }^{66}$

Since the Working Group's establishment eight years ago, indigenous peoples from all over the world have come to Geneva to speak of international law's failure to protect their human rights. In Geneva, I have heard the stories that imdigenous peoples have been telling in international human rights fornms for more than a decade. ${ }^{67} \mathrm{I}$ have histened to indigenous messengers from South America tell of gold miners who shoot Yanomami Indians from trees in the rainforest for profit-or worse, just for sport. I have heard of Indian children in the Andes poisoned by waters contaminated by the chemicals used to process cocaine. I have histened to indigenous inessengers from throughout South America speak of multimational joint ventures sponsored by settler state governments and of policies amied at national economic development through genocide.

From Central America, mdigenous messengers have spoken of the thousands of indigenous peoples who have fled death squads and wars in their countries and now crowd into refugee camps along the Mexican border. I have spoken with indigenous lawyers about the various forms of political repression exercised against traditional indigenous leaders by settler state governments. 68

66. See, e.g., Delgado, Storytelling for Oppositionists, supra note 1, at 2143; Torres \& Milun, Translating Yonnondio by Precedent and Evidence: The Mashpee Indian Case, 1990 Duke L.J. 625. This "screening function" is more thoroughly discussed infra Part V.

67. See, e.g., WG Report Sixth Session, supra note 61. These stories can be found documented in prior Working Group sessional reports, see supra note 61. For an introduction to the nature and scope of the reports and other hiterature detailing abuses of indigenous peoples' human rights globally, see Global QUEST, supra note 29, at 23-30; Nettheim, "Peoples" and "Populations"-Indigenous Peoples and the Rights of Peoples, in THE Rughts of PeopLes, supra note 4, at 107. See also the extensive bibliography of anthropologically-related materials in HUMAN RIGHTS AND ANTHROPOLOGY, supra note 4.

A summary of the major Non-Governmental Organization conferences focusing on indigenous human rights concerns can be fonnd in 1 UN INDIGENous STUDY, supra note 4, at 148-201. Among the most significant of the conferences attended by indigenous peoples during this period were the International NGO Conference on Discrimination Against Indigenous Populations in the Americas 1977 (Sept. 20-24, Geneva); Statement and Final Documents (1978), and the 1981 International NGO Conference on Indigenous Peoples and the Land (reported at Report of the Sub-Commission on Prevention of Discrimination and Protection of Minorities, U.N. Doc. E/CN.4/1512 (1983)). For accounts of the international activities of indigenous human rights groups, see Barsh, -Indigenous North America, supra note 4, at 99-102; Barsh, Emerging Object, supra note 4, at 371-72; Hannum, supra note 4, at 658-60.

68. As just one example, Jaines Anaya, now a law professor at the University of Iowa, and who represented the Miskito and other Indians of Nicaragua's Atlantic coast in their autonomy negotiations with the Sandinista government, provided me with a translated copy of a letter from the office of Sandinista Comandante Tomas Borge, "to be signed by Brooklyn Rivera and his group (the YATAMA Directorate, a Nicaraguan Indian resistance organization) in order to enter the country." 
From the Umited States, I have heard compelling stories of the human suffering of four generations of Navajo families-suffering caused by the federal government's forced relocation program on Big Mountain. ${ }^{69}$ I have heard of tribes in the Uinted States where twenty-five percent of the babies born suffer from fetal alcohol abuse syndrome, yet the Umited States Indian Health Service does hittle or nothing to provide effective prenatal education or care for pregnant Indian women.

In Geneva, I also have heard Indian people froin Canada speak of suicide and unemployment rates in their tribes that are six to eight times the national average. I heard stories of Indian mothers and their babies awakened early in the inorning by the United States' cruise missiles flying over indigenous territories which the Canadian government regards as "vacant." Fronı Australia, New Zealand, and Asia, indigenous peoples have told stories of unconipensated thefts of their territories and destruction of their subsistence-oriented, traditional ways of life.

Among the demands that were made by the Sandinistas in this letter to the then exiled Indian leaders were that they:

Recognize the authorities of the Institutions and the functionaires of the Constitutional Government of Nicaragua and not promote actions that question its legitimacy.

... Respect the laws or requirements of the Constitutional Government of Nicaragua that regulate the ingress and distribution of internal or external aid or financing for whatever type of activity.

... Renounce every type of proselytizing activity that calls into question or could undermine the normal developinent of the electoral process throughout the national territory and, in particular, in the autouomous Regious of the North and South of the Atlantic Coast of Nicaragua.

Letter from Capt. Maria Lourdes Casco to Dr. Gustavio Parajon (June 27, 1989) (available from the author). This letter, dated June 27, 1989 and signed by an official of the Ministry of Iuterior (headed by Counmander Borge who had represented the Nicaraguan Sandinista government from an early point in the Miskito autouomy negotiatious) under the caption "A Free Country or Death," was presented to Rivera and other YATAMA leaders just prior to their planned return from exile to their country. They refused to sign the letter because the provisions would have hindered fundraising activities in connection with the Nicaraguan electiou process. At the close of 1989, the Sandinistas, prodded by former President Jimmy Carter, who was called in to mediate the stalemate, agreed to drop the objectionable provisions on the couditions of entry. The Miskito leaders returned to their Atlantic Coast homelands in December 1989 to participate in the February 1990 general elections, in which the Sandinista leadership was rejected by the Nicaraguan electorate. President-elect Chamorro had promised substantial autououny to the Atlantic Coast regiou's Indian peoples. Negotiations are now being conducted betweeu the new government and the Indian leadership.

The conflict between the Sandinistas and the Miskitos has been reported on by the Inter-American Commission on Human Rights of the Organization of American States, OAS Doc. OEA/Ser. L/ V/II.62, Doc. 10 Rev. 3 (1983). A copy of the letter, news release, and other pertinent information is available from the author upon request.

69. For an assessment of the U.S. governmeut's efforts to relocate traditional Navajo families residing on lands in the region of Big Monntain, Arizona, see Whitsou, A Policy Review of the Federal Government's Relocation of Navajo Indians under P.L. 95-531 and P.L. 96-305, 27 ARIz. L. REV. 371 (1985) (concluding that courts and Congress have closed their eyes to problems of Navajo and Hopi for the past 100 years, to the benefit of certain parties and the expeuse of American Indians). 
Through such stories told to the Working Group and other international human rights forums during the past decade, indigenous peoples have described the effects of international law's continued adherence to the European doctrine of discovery. Under the exclusive jurisdiction of settler state regimes, indigenous peoples' collective rights as distinct peoples with distinct cultural identities have been demied by settler state governments. The territories they have traditionally occupied have been invaded and colonized without compensation. Their self-governing autonoiny has been systematically destroyed. Their treaties have been declared legal nullities. Such stories told by indigenous peoples for the past decade have raised consciousness in international human rights foruins about the continumg genocidal threat of the European doctrine of discovery to the survival of indigenous peoples in the world. And through the power of their stories, indigenous peoples have begun to transform legal thought and doctrine about the rights that inatter to thein under international law.

\section{Measuring the Power of Indigenous Peoples' Stories: The Working Group's Draft Universal Declaration on Rights of INDigenous Peoples}

Since its earliest sessions, the Working Group on Indigenous Populations has provided a vitally important foruin for indigenous peoples to tell their own stories, through oral and written interventions, of the human rights violations and governinent practices threatening their survival. This international fornm provides a neans of nomitoring developments that affect indigenous rights-a role that remains crucial to the Working Group's agenda.

As has been inentioned previously, during its inore recent sessions ${ }^{70}$ the Working Group also has begun to address its other, inore difficult inandated task, that of developing international legal standards for the promotion and protection of indigenous rights. ${ }^{71}$ A set of fourteen draft principles, originally released in $1985,{ }^{72}$ has evolved into the First Re-

70. See supra text accompanying notes 63-64.

71. Although the review of developments related to the human rights of indigenous peoples continues to form an important segment of the Working Group's activity, since 1985 it has shifted its focus to preparing a draft declaration on the rights of indigenous populations. From the perspective of international law, this declaration will probably be the inost significant development to date in the area of imdigenous rights. See Hannum, supra note 4, at 661 n.55.

72. See Report of the Working Group on Indigenous Populations on its Fifth Session, at 3-5, U.N. Doc. E/CN.4/Sub.2/1987, Annex II. The Working Group's original draft principles respecting indigenous peoples rights recognize:

1. The right to the full and effective enjoyment of the fundamental rights and freedoms universally recognized in existing international instruments, particularly in the Charter of the Umited Nations and the International Bill of Human Rights. 
vised Text of a Draft Universal Declaration on Rights of Indigenous Peoples, released at the Working Group's most recent 1989 session and discussed extensively at its most recent 1990 session. ${ }^{73}$ The Working Group's standard-settimg activities are intended to result in a final Draft Declaration to be forwarded ultimately to the UN General Assembly for ratification. ${ }^{74}$ Once ratified, the Universal Declaration on Rights of Indigenous Peoples will assume its place among other authoritative imternational human rights imstruments in the modern world legal order, ${ }^{75}$ as declarative of the international commumity's minimum legal standards for the protection of indigenous peoples' human rights to survival. As a standard-setting instrument for international law purposes, its alternative discourse of indigenous human rights can be einployed im international legal and political forums around the world, im the UN Commission on Human Riglits, on the floor of the UN General Asseinbly, or before regional bodies such as the Inter-American Commission on Human Rights. Not only could a United Nations Universal Declaration speakmg to indigenous human rights be cited as autlority in the mternational legal system, it would command attention and response in inany doines-

2. The right to be free and equal to all other human beings in dignity and rights, and to be free from discrimination of any kind.

3. The collective right to exist and to be protected against genocide, as well as the individual right to life, physical integrity, hiberty, and security of person.

4. The collective right to maintain and develop their ethnic characteristics and identity. 5. The collective right to protection against any act which has the aim or effect of depriving thein of their ethnic characteristics or identity. This protection shall include prevention of any form of forced assimilation, any propaganda directed against thein, etc.

6. The collective right to participate fully in the economic, political and social life and to have their specific character reflected in the legal system and in the poitical institutions of their country.

7. The duty of the territorial State to grant-within the resources available-the necessary assistance for the inaintenance of their identity and their developinent.

8. The right to special State ineasures for the immediate, effective and continuing improveinent of their social and economic conditions, with their consent, that reflect their own priorities.

9. The right to be secure in the enjoyment of their own traditional ineans of subsistence, and to engage freely in their traditional and other economic activities, without adverse discrimination.

10. The right to determine, plan and implement all health, honsing and other social and economic programs affecting them.

11. The right to manifest, teach, practise and observe their own rehgious traditions and cereinonies, and to maintain, protect, and have access to sites for these purposes.

12. The right to all forms of education, including the right to have access to education in their own languages, and to establish their own educational institutions.

13. The right to preserve their cultural identity and traditions, and to pursue their own cultural development.

14. The right to promote intercultural information and education, recognizing the dignity and diversity of their cultures.

73. WG Draft, supra note 13 , at 4.

74. See id. at 2 (mtroductory comments of Chairman-Rapporteur, Mrs. Erica-Irene Daes).

75. M. MCDougal, H. LASSwell \& L. CHEN, supra note 27, at 313-60 provides an incisive analysis of the einerging global bill of rights contained in United Nations legal instruments relating to human rights. 
tic political and legal arenas as well. Its proscriptions could be used in a variety of highly-publicized forums by any nuinber of groups and individuals to cliallenge state action which threatens the survival of indigenous peoples. Perhaps the greatest significance of a Universal Declaration on Rights of Indigenous Peoples is its capacity to translate the stories told by indigenous peoples of the liuman rights they want protected into terms that settler state governments, particularly in the West, will take seriously. ${ }^{76}$

The present Draft Declaration provides an important ineasure of the power of the stories told by indigenous peoples to transform legal thought and doctrine. It is worth renembering that the Draft was prepared by the Working Group's Chairman-Rapporteur, Mrs. Erica-Irene Daes, a respected expert in the field of international human rights law. ${ }^{77}$ Mrs. Daes, like the other expert members of the Working Group with whoin she consults on the Draft, is well-versed in international law's procedural, substantive, and nonnative discourses. In other words, the Working Group's standard-setting activities are carried out by experts familiar with the context of international law's historical denial of indigenous rights under primciples derived from the doctrine of discovery. ${ }^{78}$ Given this fact, it is significant that the Working Group Draft Declaration directly addresses the concerns that have figured inost prominently and consistently in the stories told by indigenous peoples to the Working Group and other international liuman rights forums during the past decade. ${ }^{79}$ They are the following: (1) the distinctive nature of indigenous peoples' collective rights; (2) the centrality of territorial rights to indigenous survival; (3) the recognition of indigenous peoples' rights to self-

76. See M. McDougal, H. LAsswell \& L. Chen, supra note 27, at 179-363 (discussing authoritative modes of decision for enforcing and promoting human values and dignity as reflected in international human rights instruments).

77. I have used the form of address indicated by official UN Documents, and preferred by Chairman-Rapporteur Daes herself. Mrs. Daes, of Greece, is a widely-published and respected scholar and expert in the field of international law and human rights. See, for example, her leading studies for the UN: U.N. SUBCOMM'N ON PREVENTION OF DISCRIMINATION AND Protection OF MINORITIES, THE INDIVIDUAI's DUTIES TO THE COMMUNITY AND THE LIMITATIONS ON HUMAN RightS AND FREEDOMS UNDER ARTICLE 29 OF THE UNIVERSAL DECLARATION OF HuMAN RIGHTS-A CONTRIBUTION TO THE FREEDOM OF THE INDIVIDUAL UNDER LAW, U.N. DOC. E/ CN.4/Sub.2/432/Rev.2, U.N. Sales No. E/82.XIV.1 (1983); U.N. Comm'n on Human Rights, Subcomm'n on Prevention of Discrimination and Protection of Minorities, Promotion, Protection and Restoration of Human Rights at National, Regional and Intemational Level. The Status of the Individual and Contemporary International Law, U.N. Doc. E/CN.4/Sub.2/1988/33 (1988) [herein. after The Status of the Individual]. See also Daes, Native People's Rights, 27 CAHIERs DE DroIT 123 (1986) (discussing international legal aspects of indigenous peoples' rights); Daes, On the Relations between Indigenous Peoples and States, 2 WrTHOUT PREJUdice: EAFORD INTELL. Rev. of RACIAL DISCRIMINATION 41 (1989) (discussing U.N. activities in field of indigenous rights).

78. See supra text accompanying notes 37-52.

79. See, e.g., supra notes $61 \& 67$. 
determining autonoiny; and (4) international legal protection of indigenous rights. These concerns, not coincidentally, largely have been ignored by the legal discourse derived from the doctrine of discovery, a discourse that has dominated international legal conceptions of indigenous rights for the past five centuries.

\section{A. The Rights That Matter to Indigenous Peoples}

1. Collective Rights. Under principles derived from the doctrine of discovery, indigenous peoples have, at inost, been considered entitled to no greater protection than the protection international law extends to all individuals in their relations with the state. ${ }^{80}$ In appearances before the Working Group and other international human rights forums during the past decade, however, indigenous peoples have sought to document the massive failures of existing international law to protect their collective rights to survival as distinct peoples. ${ }^{81}$

80. See, e.g., Cayuga Indians (Gr. Brit. v. U.S.), 6 R. Int'l Arb. Awards 173 (1926). The evolution of international legal recognition of the rights of the individual under international human rights law are thoroughly discussed in Daes, supra note 77.

81. The inyriad issues raised by indigenous peoples' demands for recognition of their collective rights in international law are discussed in Barsh, Indigenous North America, supra note 4, at 74-102. For a discussion of the range of theoretical and practical problems raised by the concept of collective rights in international law, see THE RIGHTS OF PEOPLES, supra note 4. The diverse views contained in the chapters by two of conteinporary international law's most powerful voices are particularly useful. See Brownlie, The Rights of Peoples in Modern International Law, in The Rughts of PeoPLES, supra note 4, at 1; Falk, supra note 4, at 17.

There are nninerous theoretical and practical problems involved in defining the collective rights belonging to "peoples" under international law. First, there is no readily identifiable, agreed upon definition of what constitutes a "people" in the international law sense of the term. Under Art. I, para. I of both the International Covenant on Economic, Social and Cultural Rights, adopted Dec. 16, 1966, entered into force, Jan. 3, 1976, 993 U.N.T.S. 3 and the International Covenant on Civil and Political Rights, adopted Dec. 16, 1966, entered into force, Mar. 23, 1976, 999 U.N.T.S. 171 (1966), the two instruments comprising the Umited Nations Human Rights Covenants, "[a]ll peoples have the right of self-determination. By virtue of that right they freely determine their political status and freely pursue their economic, social and cultural developinent." See generally Crawford, The Rights of Peoples: "Peoples" on the Governments?, in THE Rughts of PEOPLEs, supra note 4, at 55, 56-57.

Most commentators are agreed that "peoples cannot simply be identified with States." Makinson, Rights of Peoples: Point of View of a Logician, in THE Rughts OF PEOPLes, supra note 4, at 73. "[T] $]$ he two concepts are different kinds of abstraction. A people is a kind of collectivity, or group of human beings; a State is a kind of governing and administering apparatus." Id.

Despite the generally agreed upon distinction between the two terms, the international legal system has delicately avoided defining "some general characterization of what is to count as a people that will serve to distinguish 'peoples' from other 'lesser' kinds of collectivities for whom it is felt that the right to self-determination cannot reasonably be applied." Id. at 74. States have been naturally fearful of calls for self-determination from groups that might meet some definitional test of peopleliood, and therefore claim a collective right of secession. Such fears have found their embodiment in international hnunan rights legal instruments, which, it should be remembered, are approved, ratified, and inade effective by states in the international legal system. For instance, Article 6 of the 1960 UN General Assembly's Declaration of the Granting of Independence to Colomal 
The collective right to exist as distinct peoples with their own cultural identities has been one of the themes voiced most persistently since 1982 by indigenous advocates at the Working Group. ${ }^{82}$ In comments on the First Revised Text of the Draft Declaration, the Indigenous Peoples Preparatory Meeting, coinprised of a number of the indigenous human rights groups participating at the 1989 Working Group session, ${ }^{83}$ agreed on the following as a first poimt of concern relatimg to the Working Group's standard-setting activities:

1. The concept of Indigenous peoples' collective rights is of paramount importance. It is the establishment of rights of peoples as groups, and not merely the recognition of individual rights, which is one of the most important purposes of this Declaration. Without this, the Declaration cannot adequately protect our most basic interests. This must not be compromised. ${ }^{84}$

The present revised text of the Draft directly addresses this central concern about the distinctive, collective nature of indigenous peoples' rights. It affirms basic international law doctrine by guaranteeing imdigenous peoples all fundamental rights and freedoins in existing international imstruments. ${ }^{85}$ These individual rights include the right to be free

Countries and Peoples, a core text of the Third World Decolonization Movement, states in clear terms that: "Any attempt aimed at the partial or total disruption of the national unity and the territorial integrity of a country is incompatible with the purposes and principles of the charter of the United Nations." Declaration of the Granting of Independence to Colonial Countries and Peoples, G.A. Res. 1514, 15 U.N. GAOR Supp. (No. 16) at 66, U.N. Doc. A/4684 (1960).

As Makinson's essay notes, see supra, this strategy of "semantic blockage," by which the recognized collective right of self-determination belonging to a would-be "people" who constitute a subgroup of a state cannot be reconciled with the unity and territorial integrity of that state, has forced advocates secking recogirition of indigenous "peoples" human rights "to work with a very inuch diluted notion of self-determination, admitting an enormous range of degrees, so that even the least element of decentralization, evolution, or federalization is counted as constituting some ineasure of self-determination." Id. at 75-76.

It is in the context of this type of "diluted notion of self-determination" that indigenous peoples have asserted their collective rights as "peoples." See generally Netthem1, supra note 67, at 107-26:

[I]nternational law ought to be sufficient in principle to ineet the autonoiny claims of indigenous peoples ... With careful thought it may therefore be possible to devise a concept of self-determination which, while not embracing the possibility of coinplete independence against the wish of the encompassing national State, does pennit as wide a range of other forms of association as the self-determining people might select.

Id. at 120.

82. See supra note 61.

83. Indigenous Peoples' Preparatory Meeting, Comments on the First Revised Text of the Draft Deelaration on Rights of Indigenous Peoples (July 28, 1989) (available from author).

84. Id. at 1.

85. WG Draft, supra note 13 , at 5 . Paragraph 1 declares the following rights belonging to indigenous peoples: "The right to the full and effective enjoyment of all fundamental rights and freedoms, as well as the observance of the corresponding responsibilities, which are universally recognized in the Charter of the Umited Nations and in existing international human rights instruments." 
from "adverse distinction or discrimination of any kind." 86 But the Draft goes well beyond this relatively noncontroversial recognition of the mdividual human rights belonging to all indigenous peoples. The concept of collective rights, which has figured so prominently in the discourse of indigenous rights im imternational law during the past decade, ${ }^{87}$ holds a prominent place in the Working Group Draft as a basic structurimg principle of a Umiversal Declaration on Rights of Indigenous Peoples. As explained by its principal author, Mrs. Daes, the present Draft seeks to protect indigenous peoples' individual and collective rights, "with a special emphasis on the latter [collective rights] as an inherent and essential elenent of indigenous rights." 88

The Draft Declaration's express recognition of indigenous peoples' collective right "to exist as distinct peoples and to be protected against genocide," 89 would redefine significantly the ternns of indigenous peoples" status under international law. International legal discourse historically has been dominated by a conception of indigenous rights derived from the European doctrine of discovery, which demies to imdigenous peoples any distinct identity worth preserving under international law.90 The Draft Declaration's greatest significance, from the historical perspective of imdigenous peoples' rights and status under international law, is its legitimation and affirmation of the value of protecting indigenous peoples' ways of life and cultures per se. As stated in the Working Group's 1988 report explaining the need for international legal recognition of indigenous peoples' collective rights, "The harsh lessons of past history showed that recognition of individual rights alone would not suffice to uphold and guarantee the continued dignity and distinctiveness of indigenous societies and cultures."91

The specific collective rights recognized in the Draft Declaration demonstrate the power of the stories told by indigenous peoples to illustrate for the Working Group the "harsh lessons of past history." The Draft recognizes the "collective" rights of indigenous peoples to inain-

\section{Id. at 5.}

87. See supra text accompanying notes 61 \& 80-82.

88. W.G. Report, Sixth Session, supra note 61, at 18, para. 68.

89. WG Draft, supra note 13, at 6, para. 3. The UN Convention on the Prevention and Punishment of the Crime of Genocide, Dec. 9, 1948, refers specifically to members of ethnic, racial and religious groups, and prohibits "killing members of the group ...; [d]ehberately inflicting on the group conditions of life calculated to bring about its physical destruction in whole or in part ...; [i]mposing measures intended to prevent births within the group ....; [and] forcibly transferring children of the group to another group." G.A. Res. 960(III)A, 9 U.N. GAOR at 174 (1948), in Convention on Prevention and Punishment of the Crime of Genocide, Jan. 12, 1951, art. II, 78 U.N.T.S. 277, 279.

90. See supra text accompanying notes $37-52$.

91. W.G. Report, Sixth Session, supra note 61, at 21, para. 77. 
tain and develop their ethnic and cultural characteristics and distinct identities through their own traditions, religions, languages, and educational systems. ${ }^{92}$ Besides affirming indigenous peoples' rights to be protected against genocide under international law, the Draft Declaration also recognizes the need for the collective rights of indigenous peoples to be protected against ethnocide. Ethnocide is defined im the Draft as including "any act which has the aim or effect of depriving them [indigenous peoples] of their ethnic characteristics or cultural identity [or] any form of forced assimilation or integration, [such as the] imposition of foreign life-styles." 93

Throughout the past decade, indigenous peoples have consistently voiced their major concern that genocide- and ethnocide-at-law have been the only consistent features of the indigenous policies adopted by settler state regimes governed by the European doctrine of discovery. ${ }^{94}$ Responding directly to this principal concern, which also lias been reiterated continually before the Working Group, the Draft Declaration recognizes the distinct, collective nature of imdigenous rights, and thus would transform the status of indigenous peoples under international law. In offering the protection of the international legal system to mdigenous collective rights, the Working Group Draft would redefine the legal terms of indigenous peoples' cultural survival.

2. Territorial Rights. The central principle derived froin the European doctrine of discovery in contemporary imternational legal discourse relates to indigenous territorial riglits. ${ }^{95}$ Under the doctrine, as elaborated by Chief Justice Marsliall in Johnson v. M'Intosh, 96 Europeans acquired exclusive rights and control over territories they discovered even if the land were already occupied by imdigenous peoples. Upon discovery, indigenous peoples' "riglits to complete sovereiguty, as mdependent nations, were necessarily diminished, and their power to dispose of the soil at their own will, to whomsoever they pleased, was denied."97 Subsequent Western legal theorists extended the discovery doctrine's scope to deny any indigenous rights to traditionally occupied territories under mternational law. Until very recently, in fact, the dominant inter-

92. See WG Draft, supra note 13, at 6, para. 6, 8, 9, 10. Paragraph 7 of the Draft requires that states grant "within the resources available," the necessary assistance for the maintenance of indigonous peoples' identity and cultural development. Id. at 6, para. 7.

93. Id. at 6, para. 5 .

94. See, eg., Strickland, Genocide-at-Law: An Historic and Contemporary View of the Native American Experience, 34 U. KAN. L. REv. 713, 754-55 (1986) (discussing the general problen of the doctrine of discovery and indigenous peoples' hostility to settler state imtransigence).

95. See supra text accoinpanying notes 37-52.

96. 21 U.S. (8 Wheat.) 543 (1823).

97. Id. at 574. 
national legal discourse of this century regarded indigenous territories as terra nullius; that is, as lands without an owner. ${ }^{98}$

In their many stories told in Geneva and other international human rights forums, indigenous peoples have emphasized that the spiritual and material foundations of their cultural identities are sustained by their umique relationships to their traditional territories. They consistently have argued that international legal recognition of indigenous peoples' collective human rights to exist as distinct peoples pursumg their own cultural development and identity would mean hittle without a corresponding recognition of the collective nature of indigenous rights to occupy traditional territories. 99

At the Working Group's fourth session in 1985, for example, a group of twenty-two indigenous human rights organizations jointly submitted a proposed draft declaration of indigenous rights for the Working Group's consideration. The draft declaration sought international legal recognition of the special relationship of indigenous peoples to their lands and protection for indigenous territorial rights under international law. The proposed draft specifically challenged the continuing acceptance in international law of the Western settler states' asserted exclusive rights over indigenous territories derived under the doctrine of discovery. The proposed draft asserted that "[d]iscovery, conquest, settleinent on a theory of terra nullius and unilateral legislation are never legitimate bases for States to claim or retain the territories of indigenous nations or peoples."'100

The Working Group's Draft Declaration on Indigenous Peoples' Rights incorporates many of the major themes of the einerging discourse of indigenous territorial rights in international law. The Draft specifically recognizes the "collective" right of indigenous peoples to "ownership, possession and uses of the lands and resources which they have traditionally occupied or used."101 Significantly, the Working Group's rejection of the European doctrine of discovery as a legitimate basis for

98. See supra text accompanying notes 46-52.

99. As Nettheim notes in his essay, given the unique, all-encompassing and sustaining relationship indigenous peoples have with their traditional territories, recognition of indigenous peoples' land rights inust be seen as the modus vivendi for assuring their continumg cultural survival. Indigenous culture, religion and, oftentimes, even language, are intimately boimd up with indigenous peoples' continuing relationships with their land. Nettheim, supra note 67, at 116-17. Various aspeets of indigenous peoples land rights are discussed exteusively in 4 UN INDiGENOus STUDY, supra note 4, at 4-203, and in GLOBAL QUEST, supra note 29, at 43-67.

100. The Indigenous Organizations' Draft Declaration is reproduced in Annexes III and IV of the Report of the Fourth Session of the Working Group, U.N. Doc. E/CN.4/Sub.2/1985/22 (1985), quoted in Barsh, Emerging Object, supra note 4, at 380.

101. WG Draft, supra note 13, at 6, paras. $12 \& 13$. According to the wording of the Draft, indigenous peoples possess: 
determining indigenous territorial rights in international law is stated in plain terms. Indigenous peoples, according to the present wording of the Draft, possess the right to,

reclaim land and surface resources or where this is not possible, to seek just and fair compensation for the same, when the property has been taken away from them without consent, im particular, if such deprival has been based on theories such as those related to discovery, terra nullius, waste lands, or idle lands. 102

Further, States are required to provide "special ineasures" to ensure indigenous peoples' ownership and control over surface resources of their traditionally-occupied territories. For exainple, "flora and fauna, waters and ice sea" are specifically included among those resources entitled to special state protection ineasures. ${ }^{103}$

The Working Group Draft Declaration does not explicitly recognize indigenous peoples' ownership and control over the natural resources located beneath their traditional territories. It does, however, recognize a right on the part of indigenous peoples to protection of their environinent "in particular against any action or course of conduct which may result in the destruction, deterioration or pollution" of their traditional lands and surface resources. ${ }^{104}$ This right is made effective by requiring indigenous peoples' consent and 'just and fair coinpensation" for any such action or course of conduct resulting in environmental degradation of their territories. ${ }^{105}$ Additionally, the Draft Declaration requires that states consult with indigenous peoples and with both domestic and transnational corporations prior to the coininenceinent of any "large-scale" mineral and subsurface development project affecting indigenous peoples and their territories, "in order to enhance the projects' benefits and to mitigate any adverse econoinic, social, environmental and cultural effect."106 The Working Group Draft requires that indigenous peoples be given

\footnotetext{
12. The right of collective and individual ownership, possession and use of the lands or resources which they have traditionally occupied or used. The lands may only be taken away from them with their free and informed consent as witnessed by a treaty or agreement.

13. The right to recognition of their own land-tenure systems for the protection and promotion of the use, enjoyment and occupancy of the land.
}

Id. at 6 .

102. Id. at 7, para. 15. This section of the Draft goes on to state that compensation, "if the parties agree, may take the form of land or resources of quality and legal status at least equal to that of the property previously owned by them." Id.

103. Id. at 7 , para. 14 .

104. Id. at 7 , para. 16

105. Id.

106. Id. at 7, para. 17. Under the Draft, states are required to, consult with indigenous peoples and with both domestic and transnational corporations prior to the commencement of any large-scale projects, particularly natural resource projeets or exploitation of mineral and other subsoil resources in order to enhance the projects' benefits and to mitigate any adverse economic, social, environmental and cultural 
"just and fair compensation" for adverse effects resulting from any largescale resource development projects on or beneath their lands. ${ }^{107}$

These environmental mitigation and compensation requirements in the Draft Declaration seek to mandate effective state protection ineasures for indigenous peoples' recognized ownership and control rights over the surface and surface resources of their traditional territories. At the same time, the Working Group apparently has sought to avoid the sensitive political and legal issues raised by traditional state assertions of sovereignty and national control over minerals and other subsurface natural resources located in indigenous territories. The balance of these provisions, however, tilts clearly toward protection and priority of the human rights belonging to the indigenous peoples who he on the surface of those territories.

The Draft's prescriptions relating to indigenous peoples' collective rights to their lands and resources essentially would delegitimate the fivehundred-year-old legacy of the European doctrine of discovery. Rejection of the racially inspired, colomal-era legal principle that indigenous peoples possess no rights in their traditionally oceupied territories has figured prominently in the einerging discourse of indigenous rights voiced at international human rights forums during the past decade. Under the terins of the Working Group Draft Declaration, indigenous peoples' oft-repeated concern that their distinct cultural identity and existence depends on protection of their umique relationship to their traditional territories has been translated into a central principle of indigenous peoples' human rights under modern international law.

3. Self-Determination Rights. The theine of indigenous self-determination as a fundamental human right represents the inost significant challenge to present conceptions of international law posed by the einerging discourse of indigenous human rights. ${ }^{108}$ Under the European doc-

effect. Just and fair compensation shall be provided for any such activity or adverse consequence undertaken.

Id.

107. Id.

108. See Hannum, supra note 4, at 672; according to Professor Hannum:

Self-determination does unply the right, although not the necessity, of independent statehood, and governments tend to equate all demands for self-determination with independence and secession. Insistence on this formulation, even when an indigenous group desires a status less than full imdependence, may inhibit the resolution of claims that are not as wholly imcompatible as they first appear. Given the limited circumstances in which international law has thus far recognized the concept, negative government reactions to indigenous demands for self-determination are not surprising.

See also Falk, supra note 4, at 18:

Characteristically, mdigenous peoples claim to possess sovereign rights of their own and a nationality that is based on history, tradition, and self-identification. The practical consequences for rights of property, for obhigatious to pay taxes or serve in the military, for 
trine of discovery, Western settler states unilaterally denied indigenous peoples' rights to complete sovereignty over their territories. ${ }^{109}$ Since Justice Marshall's elaboration of this principle in Johnson, Western legal systems have extended the denial of indigenous self-determination far beyond the doctrine's original limitation to indigenous peoples" "power to dispose of the soil at their own will to whoinsoever they pleased."110 Settler states in the Americas, New Zealand, and Australia have denied indigenous peoples the right to practice their own religions, speak their own langnages, teach their own children, engage in their traditional means of subsistence, and govern their hives according to their own traditions and institutions. ${ }^{111}$

In the United States, where the doctrine of discovery has received its most refined articulation as a conqueror's regime of law, the United States Supreme Court in recent years has consistently interpreted the plenary power of the federal government over Indian affairs to mean that "all aspects of Indian sovereignty are subject to defeasance by Congress." 112 Acting under its plenary power derived from the doctrine, the Umited States federal government has authorized (among other genocidal and ethnocidal initiatives) the destruction of Indian rehioious sites and practices, suppression of traditional forns of tribal government, forced reinoval of Indian children from their homes, uncoinpensated seizure of treaty-protected resources, and involuntary sterilization of Indian women. ${ }^{13}$

governmental allegiance and education, are manifest and manifold. Controversy, even resistance, is the unavoidable result.

109. See supra text accompanying notes $37-52$.

110. 21 U.S. (8 Wheat.) $543,573-74$ (1823).

111. See supra note 4.

112. Escondido Mut. Water Co. v. LaJolla Band of Mission Indians, 466 U.S. 765,788 n.30 (1984); See also National Farmers Union Ins. Cos. v. Crow Tribe of Indians, 471 U.S. 845, 851 \& n.10 (1985); United States v. Wheeler, 435 U.S. 313, 323 (1978). For discussions of the cited phrase's frequent deployınent in recent Umited States Suprene Court cases, see Ball, Constitution, Court, Indian Tribes, 1987 AM. B. Found. Res. J. 3, 49; R. Williams, Learning Not to Live With Eurocentric Myopia: A Reply to Professor Laurence's Learning to Live With the Plenary Power of Congress Over the Indian Nations, 30 ARIz. L. REv. 439, 446 n.31 (1988).

113. See, e.g., Strickland, supra note 94, at 721-48 (docunients the manner in which "a culture was deliberately obliterated"). For a recent arguable example of United States genocide- and ethnocide-at-law directed at Indian religious beliefs, see Lyng v. Northwest Indian Cemetery Protection Ass'n, 485 U.S. 439 (1988). Lyng overturned a lower court affirmance for the respondents' (Yurok, Karok, and Tolawa Indians) claim that federal government intrusions on the Indians' sacred religious sites "are ... potentially destructive of the very core of Northwest [Indian] religious beliefs and practices." 565 F. Supp. 586, 594-95 (N.D. Cal. 1983). Comparc the 1948 UN Genocide Convention which defines "genocide" as an act intended "to destroy, in whole or in part, a national, ethnical, racial or religious group as such ... [c]ausing serious bodily or mental harm to members of the group." G.A. Res. 960(III)A, 9 U.N. GAOR at 174 (1948), in Convention on Prevention and Punishment of the Crime of Genocide, Jan. 12, 1951, art. II, 78 U.N.T.S. 277, 279 (emphasis added). 
International legal recognition of the right of indigenous peoples to self-determination as distimct peoples has been the most strident and persistently declared demand voiced before the Working Group. One of the most detailed and aggressive formulations of this demand is found in the 1985 Draft Declaration of Principles (Primciples) proposed by a group of inajor indigenous human rights organizations with non-governmental organization (NGO) consultative status before the Umited Nations:

All indigenous nations and peoples have the right to self-determination, by virtue of which they have the right to whatever degree of autonomy or self-government they choose. This includes the right to

The Working Group Draft Declaration defines ethnocide as "any act . . . depriving [indigenous peoples] of their ethnic characteristics or cultural identity." WG Draft, supra note 13, at 6, para. 5.

Officially sanctioned and implemented assaults on traditional tribal governments and cultures throughout the late 19 th and early 20 th centuries are critically examined in F. HoxIE, A FINAL Promise: The Campaign to Assimilate the Indians (1984).

As one commentator has noted, the forced separation of Indian children from their homes has been official policy of white governments in North America, "[e]ven before this country was a nation." Guerrero, Indian Child Welfare Act of 1978, 7 AM. INDIAN L. REv. 51 (1979). The policy continued into the 19th century. See id. at 52 . Even in this century, "[s]urveys of states with large Indian populations conducted by the Association on American Indian Affairs in 1969 and 1974 indicate that approximately $25-35 \%$ of all Indian children are separated from their families and placed in foster homes or other institutions." Id. at 53. As one state court recognized, congressional hearings leadimg to passage of the Indian Child Welfare Act of 1978, 25 U.S.C. $\$ \S 1901-1934$, see H.R. Rep. No. 1386, 95th Cong., 2d Sess. 8 (1978),

revealed a pattem of discrimination against American Indians in child welfare and child custody. Testimony indicated that for decades officials had removed a disproportionately large number of Indian children from their homes and reservations, and had placed thein in non-Indian homes and that many of the removals were unwarranted because officials showed too little deference to Indian cultural norms and denied due process in child custody proceedings. These practices deprived many children of their tribal and cultural heritage.

In the Matter of the Appeal in Pima County Juvenile Action No. 5-903, 130 Ariz. 202, 203, 635 P.2d 187, 188, cert. denied, 455 U.S. 1007 (1982).

On the United States' systemic abrogation of Indian treaties throughout the late 19th century, see F. HoxiE, supra.

Finally, federal government officials of the United States Indian Health Service continue to defend policies permitting the involuntary sterilization of Indian women. See Cook, Masterson \& Trahant, Fraud in Indian Country: A Billion Dollar Betrayal, Arizona Republic, Oct. 4-11, 1987 (series running daily for one week). The following excerpt appeared in the Arizona Republic's award-winning series:

The Indian Health Service for years has imjeeted some inentally handieapped Indian women with the drug Depo-Provera to prevent them from menstruating or becoming pregnant.

The Food and Drug Administration has twice denied approval for that long-acting hormonal drug as a contraceptive because it caused cancer in lab amimals.

The Arizona Republic revealed the IHS' use of Depo-Provera on handieapped Indian women in a 1986 investigation that prompted a congressional hearing this year where one congressnian called the IHS practice a "frighteming prospect."

However, the IFS director, Dr. Everett Rhoades, has defended the injections.

Cook, Masterson \& Trahaut, IHS Physicians Faulty or Frayed; Shortage Looms, Arizona Republic, Oct 7, 1987, at A15, A18, col. 1. See also Killing Our Future: Sterilization and Experiments, AKWESASNE NOTES, Spring 1977, at 4 (discussing sterilization of native women in the United States and abroad, and the rationale behind this activity). 
freely determine their political status, freely pursue their own economic, social, religious and cultural development, and determine their own membership and/or citizenship, without external interference. ${ }^{114}$

The Indigenous NGO Draft Declaration of Principles goes on to imply a right of indigenous secession and denies the jurisdiction of any state over an indigenous people or its territory "except in accordance with the freely expressed wishes" of the people concerned. The Principles boldly assert the right of indigenous peoples to "engage in self-defense against state actions in conflict with their right to self-determination."115

The present Draft Uinversal Declaration on Indigenous Rights responds to a nuinber of the inajor demands of indigenous peoples for recognition of their right to self-determining autonomy. Operating within the broader framework of indigenous collective rights animating the entire text, the Draft's autonoiny provisions recognize the right of indigenous peoples "to be secure in the enjoyment of their own traditional means of subsistence, and to engage freely in their traditional and other economic activities. ... In no case inay an indigenous people be deprived of its means of subsistence."116 The Draft Declaration also inandates just compensation for deprivation of indigenous peoples' right to maintain their traditional way of life $\mathrm{e}^{117}$ as well as special state measures for improving indigenous peoples' socioeconomic conditions. Such state measures, however, can be implemented only with the consent of indigenous peoples and must reflect their own priorities. ${ }^{118}$

Besides these enumerated autonomy rights, the Draft Declaration recognizes indigenous peoples' right to have "their specific character duly reflected" in the state's legal systein and in pohtical and socioeconomic institutions of the state. According to the Draft, the structure of these institutions should give "proper regard to and recognition of indigenous laws and customs." 119 The Draft also recognizes indigenous peo-

114. Draft Declaration of Principles proposed by the Indian Law Resource Center, Four Directions Council, National Aboriginal and Islander Legal Service, National Indian Youth Council, Inuit Circumpolar Conference, and the International Indian Treaty Council, reprinted in Report of the Working Group on Indigenous Populations on its Fourth Session, Annex IV, U.N. Doc. E/CN.4/ Sub.2/1985/22 (1985).

115. Id.

116. WG Draft, supra note 13 , at 7 , para. 18.

117. Id.

118. See id. at 7, para. 19. The Draft also guarantees indigenous peoples the right "to determine, plan and implement all health, housing and other social and economic programmes affecting them, and as far as possible to develop, plan and implement such programmes through their own institutions." Id. at 7 , para. 20.

119. Id. at 7, para. 21. The wording of this section recognizes indigenous peoples' right to participate on an equal footing with all the other citizens and without adverse discrimination in the politieal, economic and social life of the State and to have their specific character duly reflected in the legal system and in political and socio-economic institutions, including in particular proper regard to and recognition of indigenous laws and customs. 
ples' right to participate fully at the state level through self-chosen representatives in decisionmaking about and implementation of all national and international inatters which may affect their life and destiny. ${ }^{120}$ Their cultural autonomy rights are expressly recognized "in matters relating to their own internal and local affairs, including education, information, culture, rehigion, health, housing social welfare, traditional and often economic activities, land and resources administration and the environment."121

The Working Group Draft falls far short of recognizing a right of secession as formulated by some advocates of the einerging discourse of indigenous rights in international law. But the Draft nonetheless responds meaningfully to the repeated deinands of imdigenous peoples for international legal recoginition of their human rights through increased autonoiny in defining the terms of their survival within the legal and political systeins of their settler state governments. The Draft's autonoiny provisions therefore significantly redefine many of the doininant conceptions of inodern international law that fail to recognize any degree or aspect of the fundainental human right of self-determination belonging to indigenous peoples.

4. International Legal Status. Conteinporary international legal discourse dernes international legal status to indigenous peoples. ${ }^{122}$ This denial of status was explained by one 20th century Western international tribunal speaking with reference to American Indians but announcing the general rule applicable to all indigenous peoples colonized by Western settler states:

From the time of the discovery of America the Indian tribes have been treated as under the exclusive protection of the power which by discovery or conquest or cession held the land which they occupied. ... So far as an Indian Tribe exists as a legal unit, it is by virtue of the domestic law of the sovereign within whose territory the tribe occupies the land, and so far only as that law recognizes it. ${ }^{123}$

Denial of international legal status to indigenous peoples holds many practical as well as theoretical implications in conteniporary international law. ${ }^{124}$ For exainple, the International Court of Justice and

120. See id. at 8, para. 22.

121. Id. at 8 , para. 23.

122. See supra text accompanying notes $48-52$.

123. Cayuga Indians (Gr. Brit. v. U.S.), 6 R. Int'l Arb. Awards 173, 309 (1926).

124. Some of these implications are more thoroughly discussed im Alfredsson, supra note 29 (examines the limited remedies and avenues of redress available to imdigenous peoples); Barsh, Indigenous North America, supra note 4, at 80-102 (examining demal of international legal status to indigenous peoples as reflected in the assimilationist premise and various himian rights covenants); Clinebell \& Thomson, Sovereignty and Self-Determination: The Rights of Native Americans under 
many other more effective and high-profile forums of international law are available only to states-a term which under present conceptions of international law, does not include indigenous peoples. ${ }^{125}$ Related and just as significant is the fact that the failure to recognize indigenous peoples as formal subjects of international law's benefits and duties contributes significantly to the undermining of respect and enforceability of the hundreds of treaties between indigenous peoples and Western states. ${ }^{126}$

Europeans and European-derived goveruments have negotiated treaties with indigenous peoples since the beginnings of their encounters nearly five hundred years ago. These treaties, written in the languages of Europeans and preserved in the oral traditions and signifying texts of indigenous peoples, consistently recognize and affirm indigenous self-determination and territorial rights. Further, these treaties normally were conducted with indigenous peoples according to the various practices and protocols appropriate to subjects of international law's benefits and duties. ${ }^{127}$

Despite the existence of these treaties confirming at least soine degree of recognition of indigenous self-determination and territory in international customary law and negotiated in accordance with the rules, principles, and protocols followed by European and European-derived nations in their relations with each other, conteinporary international law does not regard these texts as holding any international legal signifi-

International Law, 27 Bufralo L. REv. 669 (1978) (the United States violates international law when it curtails the sovereignty of American Indians); Note, Self-Determination: Indians and the United Nations-The Anomalous Status of America's "Domestic Dependent Nations," 8 AM. INDIAN L. REV. 97 (1980) (arguing that the failure of the domestic trusteeship over Indian nations necessitates international recognition).

125. See generally Barsh, Indigenous North America, supra note 4, at 80-102 (discussing the effects of denial of formal international legal status for indigenous peoples). According to the Statute of the International Court of Justice, a part of the UN Charter, "[o]nly States may be parties in cases before the International Court of Justice." U.N. DEP'T of PUB. INFormation, THE INTERNATIONAL COURT OF Justice at 6, U.N. Doc. DPI/780-41027, U.N. Sales No. E.83.I.20 (1983). Russel Barsh cites two cases brought by North American Indian tribes before the ICJ in which the Court refused to exercise jurisdiction. Barsh, Indigenous North America, supra note 4, at 98.

126. See Barsh, Indigenous North America, supra note 4, at 96-98 (discussing Canada's denial of international legal status of its treaties with Indian nations).

127. For a compilation of the numerous treaties, cessions, deeds of sale and agreements negotiated between indigenous peoples and the agents of European nations in the present day United States, see EARLY AMERICAN INDIAN DOCUMENTS: Treaties AND LAWs 1607-1789 (A. Vaughan gen. ed. 1979); KAPPLER'S INDIAN AFFaIRS: LAWS AND TREATIES (1979). For an analysis of treaties involving indigenous peoples $\dot{i n}_{1}$ Canada which includes citations to various collections of documents, sec Barsh \& Henderson, Aboriginal Rights, Treaty Rights, and Human Rights: Indian Tribes and Constitutional Renewal, 17 J. CANadian Stud. 55 (1982). For New Zealand, The Treaty of Waitangi (1840) can be found reprimted in WaItangI, supra note 46, at 316-21. See generally National Indian Youth Counsel, supra note 46, at 1-6 (discussing Indian treaties and their historical status in international legal discourse). 
cance. Under the European doctrine of discovery, the indigenous party to the treaty is not entitled to the rights and obligations of sovereign states as subjects of international law. ${ }^{128}$ Rather, as explained by Canada in response to the Mikmaq Indian Nation's efforts to bring its grievances before the United Nations Commission on Human Rights, indigenous

128. Again, the Western positivists share a good part of the responsibility for the dominance of this particular negative view of indigenous rights in contemporary international legal discourse. See, e.g., W.E. HaLl, A TREaTiSe ON INTERNational LAW (P. Higgins 8th ed. 1924). Hall expressed the general consensus of the Western positivists on the non-substantive legal significance of European dealings with less civilized peoples. Despite written treaties and other formal indicia of seeining statehood under European conceptions of international law, Hall's treatise denied international legal significance to such acts between Europeans and indigenous peoples:

States outside European civilization innst formally enter into the circle of law-governed countries. They must do soinething with the acquiescence of the latter, or of soure of thein, which anounts to an acceptance of the law in its entirety beyond all possibility of misconstrnction. It is not enough consequently that they shall enter into arrangements by treaty identical with arrangements inade by law-governed powers, nor that they shall do acts, like sending and receiving permanent embassies, which are compatible with ignorance or rejection of law.

Id. at 47-48. As Jaines Anaya points out in insightful fashion iu his article, The Rights of Indigenous Peoples, supra note 46, at 193-97, the Western positivists were inuch concerned about the international legal significance of indigenous treaties. These written texts and their formalities could not be simply ignored by the positivists because they were, after all, part of the datum of European state practice. Id.

Professor Charles Alexandrowicz has demonstrated in two very valuable studies that European state practice recognized the sovereignty, territorial rights, and international status of a large variety and range of non-European civilizations and cultures for at least three centuries prior to the Western positivist era. See C.H. AlEXANDRowiCz, AN INTRODUCTION TO THE History OF THE LAW OF NATIONS IN THE EAST INDIES (1967) [hereinafter C. ALEXANDROWICZ, EAST INDIES]; C.H. ALE-

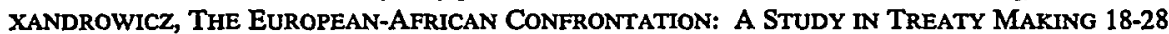
(1973). Further, the classic era writers of the European law of nations such as Grotius, Puffendorf, and Vattel all "concerned themselves with the probleins of relations between Christian and nonChristian powers and the applicability of the law of nations to transactions between thein." C. ALEXANDROWICZ, EAST INDIES, supra, at 3. Their works clearly confirmed European trcaty and diplomatic practice and its treatment of non-European societies as subjects of international law. National Indian Youth Counsel, supra note 46, at 9-24.

The positivists' response to this eupirical evidence of subjeet status for such a wide variety of less-civilized entities in international law represented, in essence, an epistemological tum. The lesscivilized, it was frequently noted, could not possibly understand the European law of nations, and therefore they could not be subject to its benefits and duties. With respeet to a treaty negotiated between European states and less-civilized entities, therefore, the natives presumptively could not understand what they were signing.

This positivist view can be found prominently displayed in the Island of Palmas Case (U.S. v. Neth.), 2 R. Int'l Arb. Awards 831 (1928). This international arbitration involved competing claims to the Island of Palmas between the Umited States and the Netherlands. The Netherlands' treaties and cessions with native rulers were not regarded as dispositive on the issue of sovereign rights to the island, though the United States could ouly claim a derived title on the basis of a claim of prior discovery of the inhabited island by Spain. The arbitration tribunal declared that "contracts between a state. . . and native princes of chiefs of peoples not recognized as meinbers of the community of nations ... are not, in the international law sense, treaties or conventions capable of creating rights and obligations. Id. at 858. Similar views can be found expressed in L. OPPENHEIM, supra note 47, at 383-90; J. WESTLAKE, supra note 47 , at 143-55. 
peoples are under the exclusive jurisdictional power of the European settler state party to the treaty:

International, American and Canadian law do not recognize treaties with North American Native People as international documents confirming the existence of these tribal societies as independent and sovereign states. These treaties are inerely considered to be nothing inore than contracts between a sovereign and a group of its subjects. ${ }^{129}$

The denial of international legal status to indigenous peoples and their treaties with States has been a principal topic of concern throughout the Working Group's sessions. Indigenous groups consistently have einphasized the importance of international legal protection of their unique status as distinct groups with collective rights. They have focused on their treaties as documents providing recognition and affirmation, not only of their international legal capacity but also of their rights to territory and self-determination in international law. Their treaties with Western nations, they have argued, confirm their rights to a distnict status as subjects of the world's international law. ${ }^{130}$

The enrerging legal discourse of indigenous rights speaks powerfully to the question of the international legal status of indigenous peoples and their treaties. According to a 1988 indigenous NGO statenrent to the Working Group,

[T] he solemnity and sacredness of treaties should be underlined.

... [ [ ] $\mathrm{t}$ is essential to recognize the historical significance and continumg relevance of treaties in formalizing relations of indigenous peoples with States and in promoting inutual trust, honour and respect.

Treaty-making is a distinct and important element, unique to indigenous peoples-no other peoples and Nations, aside from NationStates, enter into treaties with State governments. ${ }^{131}$

The Working Group Draft Universal Declaration incorporates several separate provisions that taken together would redefine the formal status of indigenous peoples and their treaties under international law. The Draft Declaration specifically recognizes the right of indigenous peoples "to claim that States honor treaties and other agreenients concluded with indigenous peoples."132 Although the word "claim" can be read to stand for inerely soine type of formal right to ask that states honor their

129. Response of the Government of Canada to the Mikmaq Nation's Greivance to the UN Human Rights Commission (1981), reprinted in Barsh, Indigenous North America, supra note 4, at 97.

130. See generally supra note 4; WG Report, Sixth Session, supra note 61, at 25-30, paras. $96-112$ (outlining study to be undertaken by Working Group unember Miguel Alfonso Martinez on treaties and other constructive arrangements between states and indigenous populations).

131. InUit Circumpolar Conference Statement on Treaty Study OUtLine 1 (1988).

132. WG Draft, supra note 13 , at 8, para. 28. 
treaties with indigenous peoples, the term should be read in the context of the Declaration's closely related recognition of where indigenous peoples can "claim" a right to treaty enforcement. The present Working Group Draft specifically recognizes indigenous peoples' collective right to access and prompt decision "by mutually acceptable and fair procedures for resolving disputes."133 These procedures, according to the Draft Declaration, should inclnde negotiations, arbitration and national courts in the domestic sphere, as well as "international and regional human rights review and complaints mechainsms."134 When linked to the right to "claim" that states honor their treaties with indigenous peoples, this broadly stated right of access to international human rights forums in particular could be used to bring indigenous peoples and their treaties within the protective scope of the international legal system. Interpreted this way, the Draft Declaration redefines indigenous peoples and their treaties as subjects of potential international legal concern and authoritative decisionmaking processes.

The Draft Declaration's recognition of indigenous international legal status indicates the power of the stories told by indigenous peoples to transform legal thought and doctrine. For nearly a decade im their appearances before international human rights bodies such as the Working Group, mdigenous peoples have sought to show that their survival in the world cannot be protected if international law continues to regard them as objects of the exclusive domestic jurisdiction of their settler state governments. Now under the terins of the Working Group Draft Declaration, indigenous peoples and their collective human rights would be redefined as subjects of direct concern to the international commumity and its "civilized" family of nations.

\section{Conclusion: The Significance of the Working Group Draft Universal Declaration on Rights of INDIGENOUS PEOPLES}

The First Revised Text of the Draft Universal Declaration on Rights of Indigenous Peoples has been described by its principal author, chairman-Rapporteur of the Working Group, Mrs. Erica-Irene Daes as

133. Id. According to the full wording of the text, indigenous peoples are recognized as possessing:

The individual and collective right to access to and prompt decision by mutually acceptable and fair procedures for resolving conflicts or disputes and any infringement, public or private, between States and indigenous peoples, groups or individuals. These procedures sliould include, as appropriate, negotiations, mediation, arbitration, national courts and Id. international and regional human rights review and coinplaints inechanisms.

134. Id. 
"a realistic approach to the issues," constituting "a fair balance between the aspirations of indigenous peoples and the legitimate concern of States."135 Even so, the present Draft Declaration, as Mrs. Daes concedes, has generated "a diversity of opimons," which liave becoine evident "in the observations inade by the Governments, on tlie one hand, and by indigenous organizations, on the other, in particular on provisions as to land and resources rights, self-government and self-autonomy."136 Despite these differences, Daes has insisted that all future substantial clianges to the Draft "have to be acceptable to all parties concerned."137

Without doubt, therefore, the debates in Geneva between governments and indigenous peoples on the standard-setting efforts of the Working Group represent one of the inost important encounters occurring on the frontiers of international human riglits law. Eventual adoption by the General Assembly of the Working Group's Draft Declaration could provide a umque stimulus to the contemporary global movement for recognition, protection, and promotion of indigenous peoples' huinan rights. ${ }^{138}$

The Draft's broad scope of recognition for indigenous human rights already addresses many of the more serious concerns raised since 1982 by indigenous peoples during the course of their interventions to the Working Group. ${ }^{139}$ Although the present Draft hikely will undergo substantive revision and refinement of terms, the core concepts of indigenous peoples' collective rights, territorial riglits, self-deterinining autonomy rights, and international legal status have been firmly recognized by the Working Group as indispensable elements of any international legal instrument devoted to the protection of indigenous peoples' survival. ${ }^{140}$ As evidenced by the Draft Declaration itself, througli their stories told in Geneva and in other human rights forums during the past decade, indigenous peoples lave begun to redefine the terms of their survival in international law.

135. WG Draft, supra note 13 , at 3 .

136. Id.

137. Id. The comments on the Working Group Draft Declaration submitted by states and indigenous organizations contained in Discrimination Against Indigenous Peoples: Analytical Compilation of Observations and Comments, U.N. Doc. E/CN.4/Sub.2/1989/33/Add.1 (1989) [hereinafter Analytical Compilation], provide an excellent overview of the diversity of opinions.

138. In the words of Professor Hannum, supra note 4, at 650: "In the context of an increasing awareness of human rights generally and the recognition of the particular problems of disadvantaged groups, mdigenous peoples and their representatives have been in the vanguard of attempts to deal with ethnic and other conflicts by invoking or creating international norms."

139. See, e.g., supra note 61; Analytical Compilation, supra note 137 (providing statements, concerns, and proposals by interested governments and imdigenous peoples' organizations).

140. See WG Report, Sixth Session, supra note 61, at 18, para. 68 (comments of ChairmanRapporteur Daes). 
Evaluating the modest successes achieved to date by indigenous peoples and their advocates in the international human rights process provides a unique opportunity to enrich our understanding of a nuniber of subjects of concern to critical race theory and scholarship. Throughout their works, critical race scholars have underscored the need to develop a more sophisticated understanding of the strategic functioning of rights discourse in the social movements of peoples of color. ${ }^{141}$ As Kimberle Williams Crenshaw stated: "Attempts to harness the power of the state through the appropriate rhetorical/legal incantations should be appreciated as intensely powerful and calculated pohitical acts. In the context of white supremacy, engaging in rights discourse should be seen as an act of self-defense." 142

In the context of the contemporary indigenous struggle for survival and international legal protection, rights discourse has functioned effectively in generating a shared, empowering vocabulary and syntax for indigenous peoples. The discourse of international human rights has enabled indigenous peoples to understand and express their oppression in terms that are meaningful to them and their oppressors. Thinking in terms of rights has organized indigenous peoples on a global scale to combat their shared experiences of being excluded and oppressed by the dominant world order. ${ }^{143}$ The use of rights rhetoric in international human rights standard-setting bodies such as the Working Group illustrates the ways in which indigenous people can transform the dominant perception of their rights in the international context. Again relying on Professor Crenshaw's imsights,

Powerless people can sometimes trigger ... a crisis by challenging an institution internally, that is, by using its own logic against it. Such a crisis occurs when powerless people force open and politicize a contradiction between the dominant ideology and their reality." ${ }^{144}$

The power of indigenous peoples' own stories in dramatically redefining the reality of their struggle for survival in the world underscores the capacity of narrative to transform legal thought and doctrine about

141. See, e.g., Crenshaw, supra note 1; Delgado, Ethereal Scholar, supra note 1; P. Williams, supra note $1 ; \mathrm{R}$. Williams, supra note 1.

142. Crenshaw, supra note 1 , at 1382.

143. As Professor Crenshaw has observed in reflecting on the organizing function of rights discourse in the experience of the black civil rights movement in this country:

Perhaps the action of the Civil Rights community was effective, for example, because it raised the novel idea of Blacks exercising rights. Indeed, thinking in terms of rights may have been a radical and liberating activity for Blacks.... The expression of rights ... was a central organizing feature of the civil rights movement.

Id. at 1364.

144. Id. at 1367 (footnote omitted). 
rights. This central insight about the power of stories is explored frequently in the works of a number of critical race scholars. ${ }^{145}$

Reliance on narratives of government abuses and assaults on indigenous survival that can be easily translated in the legal language of international human rights norms las proved extreinely effective for indigenous peoples to raise consciousness at the international level about the human rights that matter to them. In an article appearing in this Symposium, ${ }^{146}$ Professor Gerald Torres has sought to draw our attention to the importance of permitting indigenous peoples and outsider groups generally to tell their stories in terms that account for their own experience of the world rather than the experience of the dominant group. As Professor Torres relates, the Mashpee Indians were disabled from telling their story in a Umited States federal court by legal rules that worked to silence their claims. Their stories, Torres coinpellingly laments, "were stories that legal ears could not liear."147

Thus, the Working Group Draft Declaration would seem to provide some useful, einpirically-grounded evidence to support the beliefs of critical race scliolars about the power of stories to transform legal thought and doctrine. But perhaps even more importantly, the Draft Declaration also provides a rare glimpse of what happens in a formalized legal setting when disempowered groups are not required to legitimate crucial aspects of their alternative legal visions in terms dictated by standing and evidentiary standards that are not designed with thein in mind.

The Working Group Draft Declaration also affirms the important roles fairness and formality inust play if rights rhetoric and consciousness-raising through narrative are to be effective tools for the social movements of peoples of color. Several critical race theorists, inost notably Professor Richard Delgado, ${ }^{148}$ have argued that bias and prejudice among legal decisionmakers and disputants are most likely to be counteracted through fair reliance on fornal procedures apphed in open adjudicatory settings in which "public" values-values such as equality and dignity-are allowed to come to the fore. ${ }^{149}$

Aceording to Professor Delgado, the risks of prejudice leading to the demal of justice are greatest when a neinber of an oppressed group

145. See, eg., D. BELI, supra note 1; Delgado, Storytelling for Oppositionists, supra note 1; Matsuda, supra note 1.

146. See Torres \& Milun, supra note 66 , at 625 .

147. Id. at 649.

148. See, eg., sources cited in supra note 25. See also Matsuda, supra note 1, at 2325 (describing why measures to eliminate effects of oppression "are best implemented through formal rules, formal procedures and formal concepts of rights, for informality and oppression are frequent fellowtravelers.").

149. See Delgado \& Dunn, Minimizing Risk, supra note 25, at 1387-91. 
confronts an oppressor directly and when there are few rules to constrain conduct; when the setting is closed and does not make clear that "public" values are to govern the confrontation; and when the confrontation touches a sensitive area of life, such as culture-based conduct. ${ }^{150}$

Unfortunately, too many of these factors liave combined to deny justice in situations in which indigenous peoples and their advocates lave sought to tell their stories of the rights that matter to thein before the domestic political and legal systeins of settler state governments. Even in the United States ${ }^{151}$ - which is regarded as having one of the world's most progressive reeords when it coines to inodern-day protections for indigenous rights ${ }^{152}$-American Indian tribes must lobby and litigate the terms of their survival under a regime of law that treats their collective rights as peoples as subject to complete defeasance by a conquering government. In the United States, the courts of the conqueror liave vested Congress with plenary power to define Indian rights, constrained only by a weakly interpreted "trust" responsibility that Congress itself can define, limit, or terminate at its own political wlimı or caprice. ${ }^{153}$

In other settler states, the situation is far worse. Indigenous rights in inany countries are not even recognized in domestic law and policy. Often times, states impose forced assimilation prograns upon indigenous peoples and regard any questioning of their imdigenous policies by other international actors as unjustified impertinence towards a sovereign state under international law. In Latin America and Asia, for example, decisions about the cultural survival of indigenous peoples are inade in distant capitols and boardrooms of multinational corporations without ever listening to the views or preferences of indigenous peoples about the riglits that matter to thein.

The Working Group, lowever, has allowed indigenous peoples to tell their stories and thereby humanize their struggles. States have had to respond and explain their actions and policies that endanger the survival of indigenous peoples through the mediary capacity of the Working Group. The Working Group, it sliould be remembered, is a fact-finding and standard-setting body coinposed of a racially and culturally diverse group of individuals-all of whom serve in their individual capacities as liuman rights experts. The highly charged and sensitive issues raised

150. Id.

151. See supra text accompanying notes 112-13.

152. See, eg., C. WILKINSON, AMERICAN INDIANS, TIME AND THE LAW 5 (1987) (noting that "the policy of the United States towards its native people is one of the most progressive of any nation").

153. See R. Williams, supra note 15 , at $289-91$ (describing United States federal Indian law principles of congressional plenary power and trust). 
when settler state practices and laws threaten the cultural beliefs and ways of life of indigenous peoples liave had to be discussed in the context of the "public" values animating and sustaining the international luunan riglits process. Actors in settings sucl as a United Nations luman rights standard-setting body are not likely to express the biased and prejudiced views of indigenous culture that often are refiected in doniestic policies, law, and decisioumaking. The "equal status contact" between indigenous peoples and settler states before the Working Group strongly reaffirms the public values of common humanity, dignity, equality and elimination of all forms of racial prejudice widely perceived as informing the international human rights process. ${ }^{154}$

In conclusion, despite the deinals by soine legal academics of the efficacy of rights discourse and storytelling in the social movenients of peoples of color, ${ }^{155}$ indigenous peoples of color liave deinonstrably benefited by their reliance on these liberating forms of discourse applied in the formalized standard-setting activities of the international lumian rights process. Standard-setting bodies like the Working Group provide previously unavailable, formally structured opportunities for open dialogue and encounter that enable indigenous peoples to define the precarious terms of their survival im the world under the European doctrime of discovery. Drawing on their histories, traditions, experiences, and the sheer weiglit of their testimıny, mdigenous peoples lave convincingly denıonstrated to the Working Group that the present, dommant conceptions of their rights and status in international law lave failed to protect their human rights to survival. The United Nations Working Group's Draft Universal Declaration on Riglits of Indigenous Peoples, therefore, provides a powerful and enipowering nistance of the ways in which peoples of color, such as indigenous peoples, througli their own stories, can seek to transform legal thought and doctrine about their luunan rights according to the terins of a different vision of justice in the world.

154. See Delgado \& Dunn, Minimizing Risk, supra note 25, at 1386 (describing benefits of "equal status contact" for outsider groups).

155. See supra text accompanying notes 1-3. 